\title{
On graduation from fiscal procyclicality ${ }^{\text {tr }}$
}

\author{
Jeffrey A. Frankel ${ }^{\mathrm{a}, \mathrm{d}}$, Carlos A. Vegh ${ }^{\mathrm{b}, \mathrm{d}}$, Guillermo Vuletin ${ }^{\mathrm{c}, *}$ \\ a Harvard University, Cambridge, MA, USA \\ b University of Maryland, College Park, MD, USA \\ c Colby College, Waterville, ME, USA \\ d NBER, Cambridge, MA, USA
}

\section{A R T I C L E I N F O}

Article history:

Received 26 September 2011

Received in revised form 9 April 2012

Accepted 9 July 2012

\section{JEL Classification:}

E62

E32

E02

F41

Keywords:

Business cycle

Institutional quality

Cyclicality

Procyclicality

Countercyclicality

Graduation

Emerging markets

\begin{abstract}
A B S T R A C T
In the past, industrial countries have tended to pursue countercyclical or, at worst, acyclical fiscal policy. In sharp contrast, emerging and developing countries have followed procyclical fiscal policy, thus exacerbating the underlying business cycle. We show that, over the last decade, about a third of the developing world has been able to escape the procyclicality trap and actually become countercyclical. We then focus on the role played by the quality of institutions, which appears to be a key determinant of a country's ability to graduate. We show that, even after controlling for the endogeneity of institutions and other determinants of fiscal procyclicality, there is a causal link running from stronger institutions to less procyclical or more countercyclical fiscal policy.
\end{abstract}

(c) 2012 Elsevier B.V. All rights reserved.

\section{Introduction}

The cyclical behavior of fiscal policy differs across countries by income group. In the past, while industrial countries have tended to pursue fiscal policy that is countercyclical or at worst acyclical, developing countries have tended to follow procyclical fiscal policy: they have increased spending (or cut taxes) during periods of expansion and cut spending (or raised taxes) during periods of recession. Many authors have documented that fiscal policy has tended to be more procyclical in developing countries than industrialized countries. ${ }^{1}$ Most studies look at the procyclicality of government spending because tax receipts are endogenous with respect to the business cycle. Indeed, an important reason for

\footnotetext{
is We would like to thank seminar participants at the IMF, World Bank, Central Bank of Chile, Central Bank of Hungary, and, especially, the editor and two anonymous referees for helpful comments and suggestions. Guillermo Vuletin acknowledges the Division of Social Sciences at Colby College for financial support.

* Corresponding author at: 5235 Mayflower Hill, Waterville, ME 04901-8852, USA. Tel.: +1 207872 6430; fax: +1 2078595248 .

E-mail address: gvuletin@colby.edu (G. Vuletin).

${ }^{1}$ See Gavin and Perotti (1997), Tornell and Lane (1999), Kaminsky et al. (2004), Talvi and Vegh (2005), Mendoza and Oviedo (2006), Alesina et al. (2008), and Ilzetzki and Vegh (2008).
}

procyclical spending is precisely that government receipts from taxes or mineral royalties rise in booms, and the government cannot resist the temptation or political pressures to increase spending proportionately, or even more than proportionately. A similar procyclical pattern can be found on the tax side by focusing on tax rates rather than revenues, though cross-country evidence is harder to come by. Vegh and Vuletin (2012) find that tax rate policy has been mostly procyclical in developing countries and acyclical in industrialized countries.

In terms of government spending, the contrast between the two groups of countries can be clearly seen in Fig. 1, which updates evidence presented in Kaminsky et al. (2004). The figure depicts the correlation between (the cyclical components of) government spending and GDP for 94 countries ( 21 developed and 73 developing countries) for the period 1960-2009. Black bars represent industrial countries while light bars represent developing countries. A positive (negative) correlation indicates procyclical (countercyclical) government spending. ${ }^{2}$ The visual image tells the whole story: light bars lie overwhelmingly on the right hand side (positive correlations) while black bars dominate the left

\footnotetext{
${ }^{2}$ Needless to say, correlations do not tell us anything about causality which, in principle, could go in either direction. Ilzetzki and Vegh (2008), however, show that, even when properly instrumented, output does cause government spending, as emphasized by the fiscal procyclicality literature.
} 


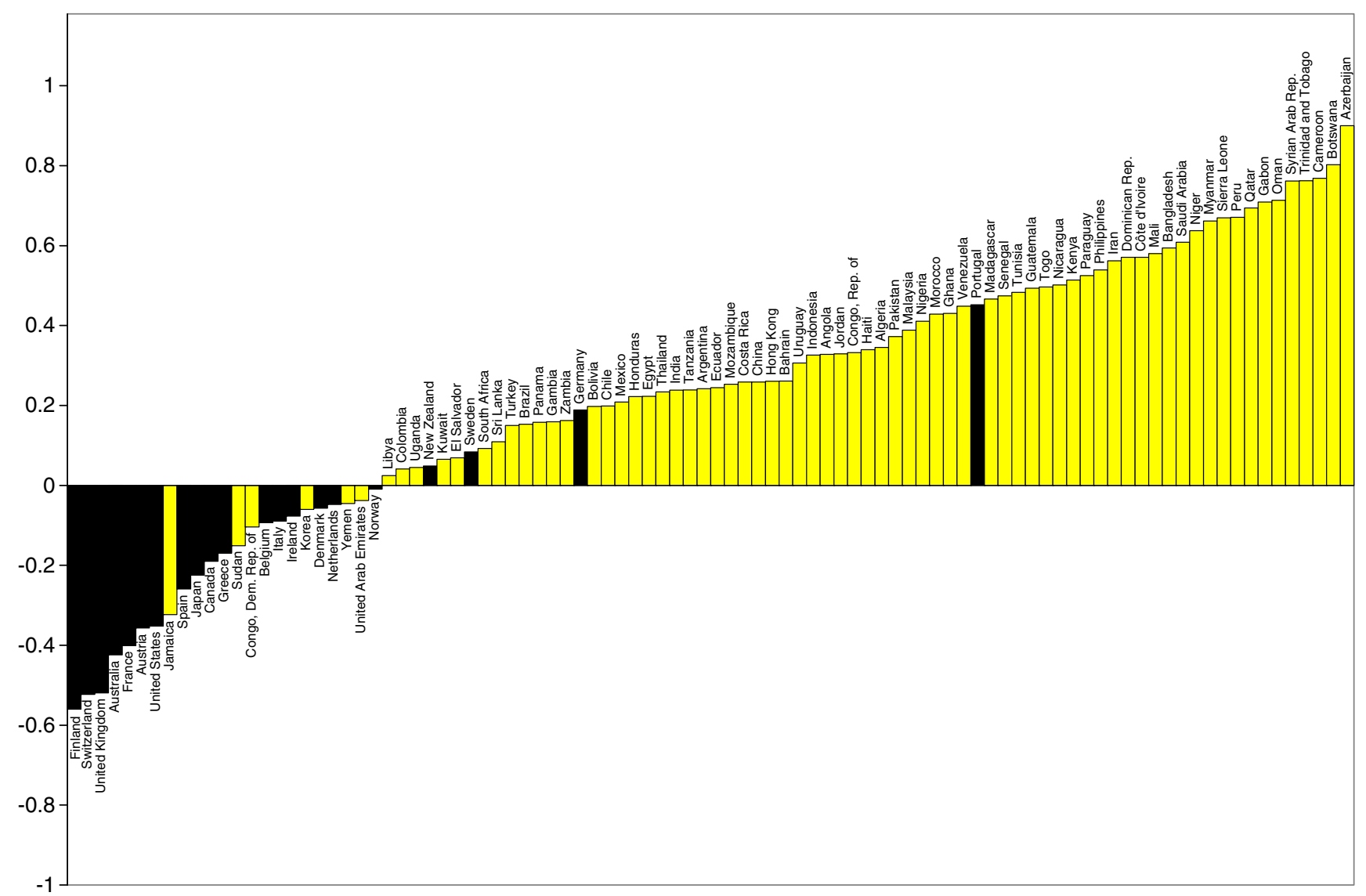

Fig. 1. Country correlations between the cyclical components of real government expenditure and real GDP. 1960-2009. Notes: Dark bars are industrial countries and light ones are developing countries. The cyclical components have been estimated using the Hodrick-Prescott Filter. A positive (negative) correlation indicates procyclical (countercyclical) fiscal policy. Real government expenditure is defined as central government expenditure and net lending deflated by the GDP deflator. See Appendix 2 for correlation values for each country.

Source: World Economic Outlook and International Financial Statistics (IMF).

hand side (negative correlations). Indeed, more than $90 \%$ of developing countries (67 out of 73 ) show procyclical government spending, while around $80 \%$ of industrial countries (17 out of 21 ) show countercyclical government spending.

Why would policymakers pursue procyclical fiscal policy? After all, such policy cannot be optimal since it will tend to reinforce the business cycle, exacerbating booms and aggravating busts. The most convincing explanations in the literature fall in two, not necessarily inconsistent, camps: (i) imperfect access to international credit markets and lack of financial depth (Caballero and Krishnamurthy, 2004; Gavin and Perotti, 1997; Gavin et al., 1996; Riascos and Vegh, 2003) and (ii) political distortions (Talvi and Vegh, 2005; Tornell and Lane, 1999; Velasco, 1997). ${ }^{3}$ Lack of access to credit markets in bad times will naturally leave governments with no choice but to cut spending and raise taxes, whereas political pressures for additional spending in good times are hard to resist, particularly when there may exist a genuine need for more government spending in critical social areas. Improving access to credit in bad times (including official financial assistance from multilateral financial institutions such as the IMF) and designing rules and institutions that aim at ensuring that fiscal revenues are saved in good times so that they are available in bad times would go a long way to alleviate the scourge of procyclical fiscal policy.

In fact - and as we will argue in this paper - over the last decade several developing countries have been able to "graduate" in the sense of overcoming the problem of procyclicality and becoming

\footnotetext{
${ }^{3}$ Calderón and Schmidt-Hebbel (2008) provide evidence for the empirical relevance of these two channels.
}

countercyclical. ${ }^{4}$ Theoretical work by Christiano et al. (2011) and Nakata (2011) clearly suggests that this shift in the cyclical properties of fiscal policy is welfare improving since the optimal fiscal policy in a stochastic model with sticky prices is countercycical. In fact, both papers show that countercyclical fiscal policy is even more effective when monetary policy has become powerless because the policy interest rate has hit the zero bound. Intuitively, suppose the economy is hit systematically (in a stochastic sense) by, say, shocks to the discount factor. In bad times (when the preference shock induces household to save more), it becomes optimal for the government to increase spending (even to the point of making the zero bound marginally non-binding if it was binding to begin with). ${ }^{5}$

Chile is undoubtedly the poster child of this graduation movement. As discussed in Frankel (forthcoming), since 2001 Chile has followed a fiscal rule that has a structural (i.e., cyclically-adjusted) fiscal balance as its target. ${ }^{6}$ By construction, such a rule ensures that temporarily high fiscal revenues are saved rather than spent. But, as we will show below, Chile is not the only country that seems to have escaped the procyclicality trap.

\footnotetext{
${ }^{4}$ Our work can be viewed as complementing, on the fiscal side, recent work by Reinhart et al. (2010) who study graduation from default, inflation, and banking crises, and Vegh and Vuletin (forthcoming) who study graduation from monetary procyclicality.

${ }^{5}$ Christiano et al. (2011) derive this result taking monetary policy as given. Nakata (2011), however, shows that countercyclical fiscal policy is optimal even if monetary policy is chosen optimally.

6 The original target was a structural surplus of $1 \%$, reflecting the need to repay Central Bank debt associated with the bailout of private banks in the 1980s. As this debt was paid off over time, the targeted structural balance was reduced to $0.5 \%$ in 2008 and $0 \%$ in 2009.
} 
Our analysis confirms previous findings in the literature regarding the role of increased financial integration and lower output volatility in reducing fiscal procyclicality. The paper's main focus, however, is on the role played by the quality of institutions. We argue that the quality of institutions seems to be a key determinant of a country's ability to graduate and show evidence that as the quality of institutions increases over time, the level of procyclicality falls.

The paper proceeds as follows. Section 2 shows the shift in fiscal policy in many emerging and developing countries over the last decade. Section 3 traces this shift to the quality of institutions and presents some basic regressions that establish a negative correlation between fiscal procyclicality and the quality of institutions. Moreover, we show that a marked improvement in institutional quality witnessed during the last 25 years in some developing countries seems to be at the root of their "graduation." Sections 4 and 5 go a step further and control for other determinants of procyclicality and address endogeneity concerns. We show that there is a strong case to be made that causality indeed runs from the quality of institutions to less procyclical or countercyclical fiscal policy. Concluding remarks can be found in Section 6.

\section{Graduating class}

This section documents the important shift in the cyclical behavior of fiscal policy over the last decade in the developing world. To this end, we divided the 1960-2009 sample used in Fig. 1 into two sub-samples: 1960-1999 and 2000-2009. Fig. 2 replicates Fig. 1 for the period 19601999 and conveys essentially the same message. Fig. 3, on the other hand, focuses on the period 2000-2009. Once again, the visual image conveyed by Fig. 3 is striking when compared to Fig. 2. Specifically, the number of light bars on the left-side of the picture (i.e., negative correlations) has greatly increased. Around $35 \%$ of developing countries (26 out of 73 ) now show a countercyclical fiscal policy, up from $8 \%$ ( 6 out of 73 ) in Fig. 2.

To illustrate graduation, Fig. 4 presents a scatter plot with the 1960 1999 correlation on the horizontal axis and the 2000-2009 correlation on the vertical axis. By dividing the scatter plot into four quadrants along the zero axes, we can classify countries into four categories:

1. Established graduates (bottom-left): These are countries that have always been countercyclical. Not surprisingly, $87 \%$ of the countries in this category are industrial countries, including the United States, United Kingdom, and Australia.

2. Still in school (top-right) These are countries that have continued to behave procyclically over the last decade. Again not surprisingly, $96 \%$ of these countries are developing countries, including Venezuela, Peru, and India.

3. Back to school (top-left): These are countries that were countercyclical during the 1960-1999 period and turned procyclical over the last decade. This small group of countries is split fairly evenly between developed and developing countries. It includes Greece and Jamaica.

4. Recent graduates (bottom-right): These are countries that used to be procyclical and became countercyclical over the last decade. They are mostly represented by developing countries (24 out of 26 , or 96\%) and include Chile, Brazil, and Botswana.

In sum, the evidence suggests that about a third of the developing world (24 out of 73 countries) has recently "graduated" from procyclicality.

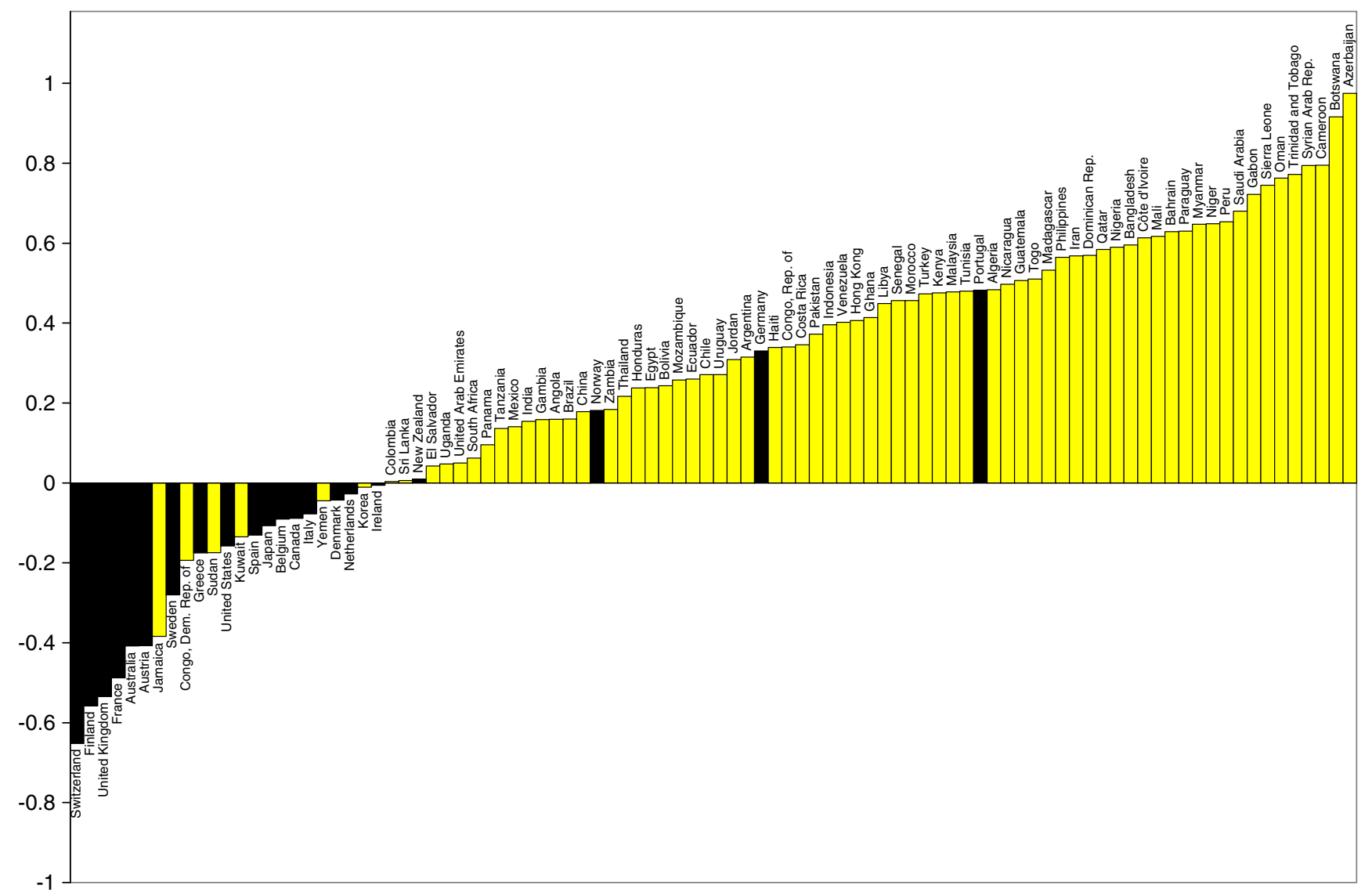

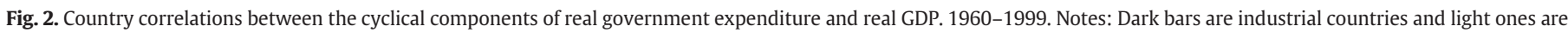

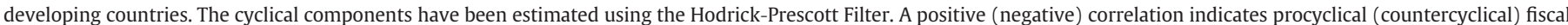

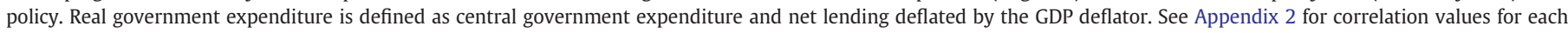
country.

Source: World Economic Outlook and International Financial Statistics (IMF). 


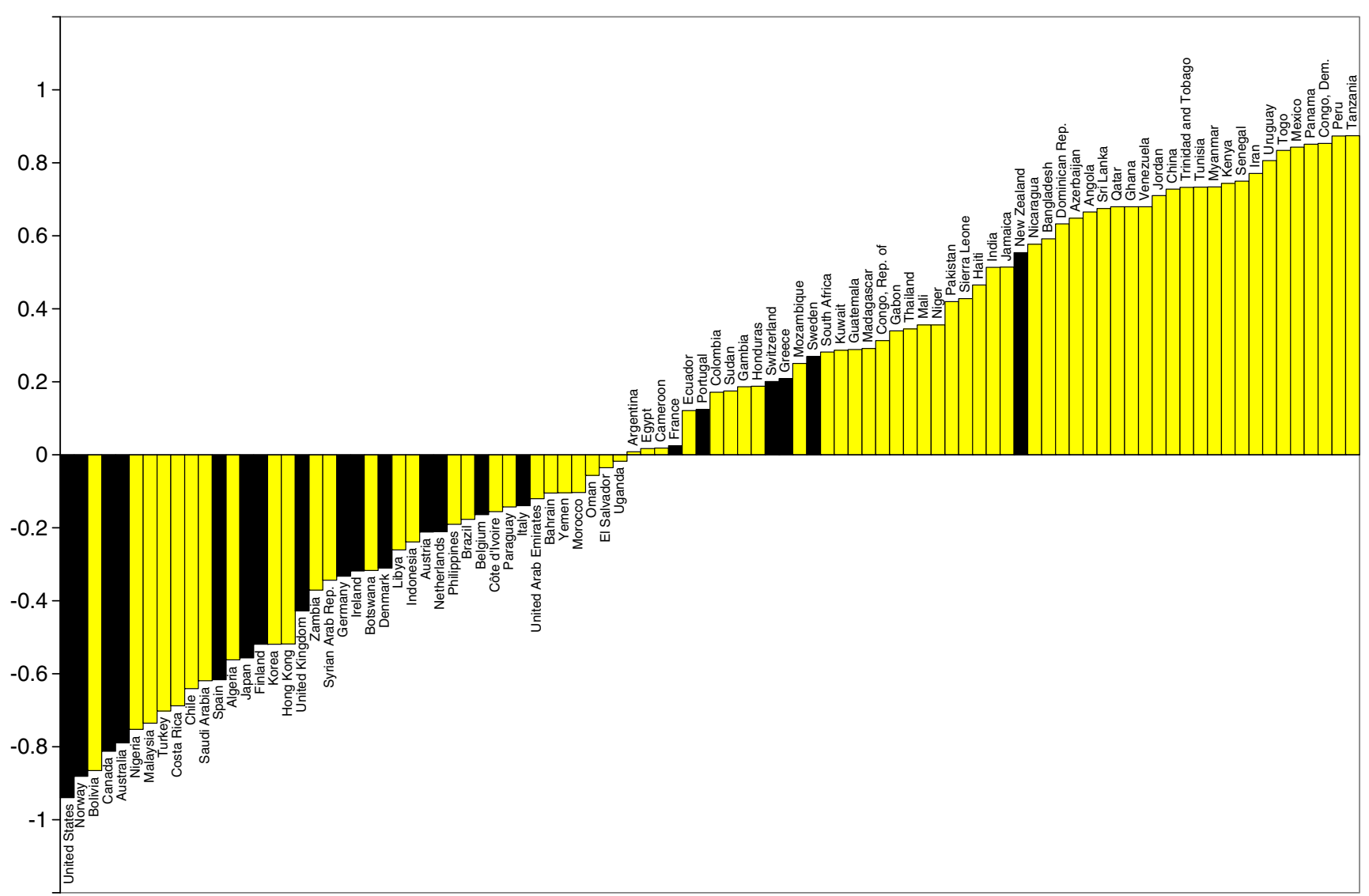

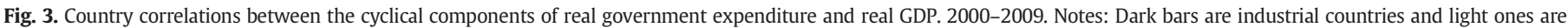

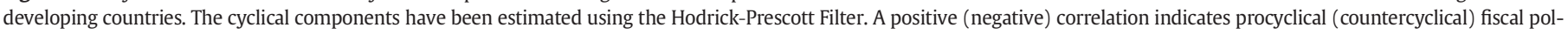

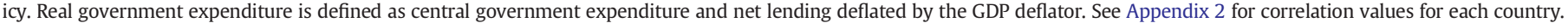
Source: World Economic Outlook and International Financial Statistics (IMF).

The evidence of countercyclicality among many emerging market and developing countries matches up with other criteria for judging maturity in the conduct of fiscal policy: debt-GDP ratios, rankings by rating agencies, and sovereign spreads. Low income and emerging market countries in the aggregate have achieved debt-GDP levels around $40 \%$ of GDP over the last four years. The IMF estimates the 2011 ratio at $43 \%$ among emerging market countries and 35\% among low-income countries. This is the same period during which debt in advanced countries has risen from about 70\% of GDP to $102 \%$. The financial markets have ratified the historic turnaround. Spreads are now lower for many emerging markets than for some "advanced countries." As of early 2012, Singapore has a higher credit rating than France or the US; Chile has a higher credit rating than Japan; Korea and China have higher credit ratings than Spain; Malaysia, South Africa, Brazil, and Thailand all have higher ratings than Italy; Colombia has a higher rating than Iceland or Ireland; Indonesia and the Philippines have higher ratings than Portugal; and various African countries have higher ratings than Greece.

Largely as a result of their improved fiscal situations during the period 2000-2007, many emerging markets were able to bounce back from the 2008-2009 global financial crisis more quickly than advanced countries. $^{7}$

\section{Graduation and institutional quality}

What explains the ability of some countries, particularly emerging market and developing countries, to escape the trap of procyclical fiscal policy? Many researchers have pointed to the importance of institutions

\footnotetext{
${ }^{7}$ See, for example, Didier et al. (forthcoming).
}

in determining various aspects of public policy. ${ }^{8}$ In this spirit, this section shows that institutional quality (IQ) explains some of the most recent changes in cyclicality of fiscal policy. To this effect, we construct an index of IQ by calculating the average of four normalized variables from the International Country Risk Guide dataset:

- Investment profile: An assessment of factors affecting investment risk that are not covered by other political, economic and financial risk components. The risk rating assigned is the sum of three subcomponents: contract viability/expropriation, profits repatriation, and payment delays.

- Corruption: An assessment of corruption within the political system.

- Law and order: An assessment of the strength and impartiality of the legal system and the popular observance of the law.

- Bureaucratic quality: An assessment of the strength and expertise to govern without drastic changes in policy or interruptions in government services.

The IQ index ranges between 0 (lowest institutional quality) and 1 (highest institutional quality).

We first establish a link between the four way classification in Fig. 4 and IQ. To this effect, Column 1 in Table 1 reports the average IQ for each of these groups. As hypothesized, the highest IQ is for the "established graduates" group. Next is the "back to school" group with an average index of 0.6 , followed by the "recent graduates" group with an average index of 0.55 . The "still in school" countries have the lowest

\footnotetext{
8 The importance of institutions for fiscal policy has been emphasized by Buchanan (1967), von Hagen and Harden (1995), Alesina and Perotti (1996), Poterba and von Hagen (1999), Persson and Tabellini (2004), and Calderón and Schmidt-Hebbel (2008), among others.
} 


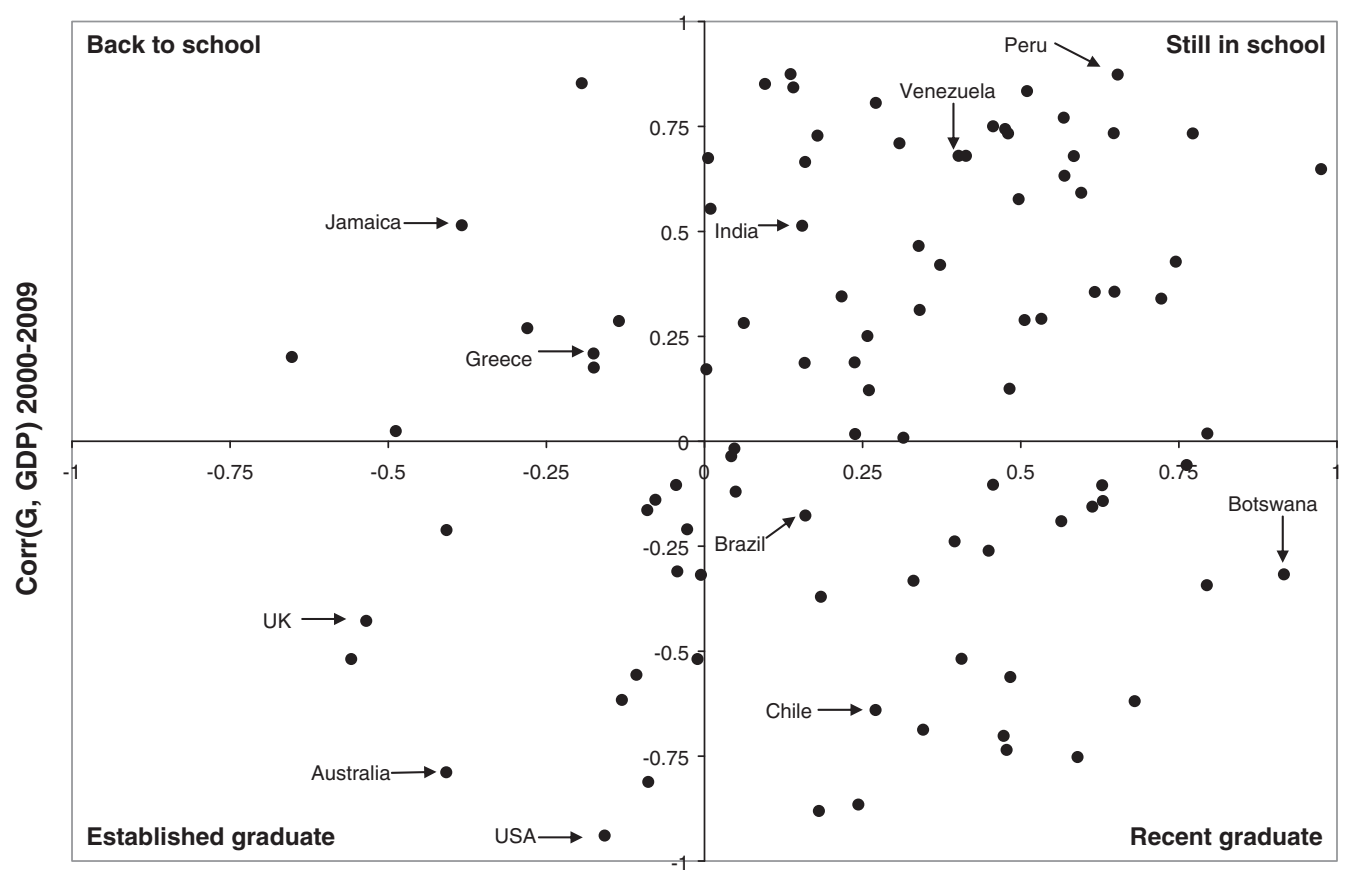

Corr(G, GDP) 1960-1999

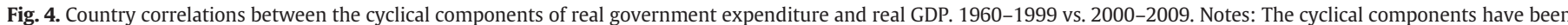

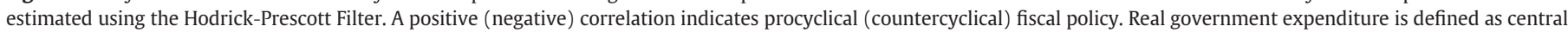

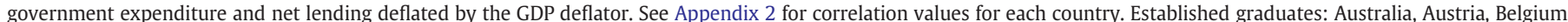

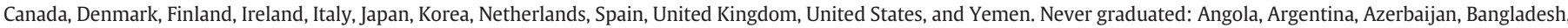

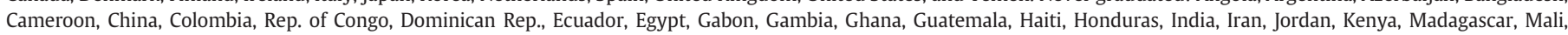

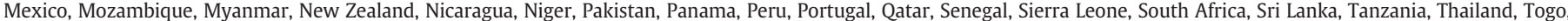

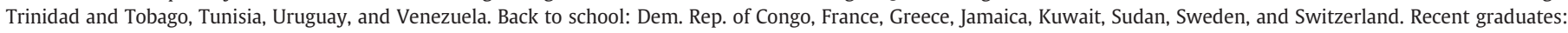

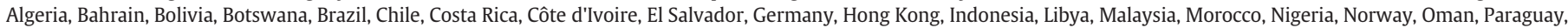
Philippines, Saudi Arabia, Syrian Arab Rep., Turkey, Uganda, United Arab Emirates, and Zambia.

Source: World Economic Outlook and International Financial Statistics (IMF).

institutional quality (0.48). All these IQ differences are statistically significant at the $1 \%$ level.

We then construct a scatter plot relating IQ and procyclicality, shown in Fig. 5. We can see a clear negative relationship between IQ and cyclicality of fiscal policy. The higher (lower) the IQ in a country, the more countercyclical (procyclical) is fiscal policy. Based on the estimated regression, an IQ level of 0.79 supports acyclicality. A higher (lower) level of IQ supports countercyclicality (procyclicality).

In order to further explore the importance of IQ in the process of graduation from procyclicality, we decompose IQ values in each country into two components; $\mathrm{IQ}^{\text {initial }}$ and $\Delta \mathrm{IQ}$. IQ ${ }^{\text {initial }}$ refers to the initial (or earliest) IQ observed. In most countries this value corresponds to the IQ level in $1984 .{ }^{9} \Delta \mathrm{IQ}$ is then defined as the difference between the current IQ value and IQ ${ }^{\text {initial }}$. In other words, $\Delta \mathrm{IQ} \equiv \mathrm{IQ}-$ $\mathrm{IQ}^{\text {initial }}$. Columns 2 and 3 in Table 1 show the average $\mathrm{IQ}^{\text {initial }}$ and $\Delta \mathrm{IQ}$ for each of these groups.

We should take the findings for the "back to school" group with a grain of salt given the small sample included in this group; only 8 countries (see top-left quadrant in Fig. 4). Column 2 shows that, as expected, the highest initial IQ (0.84) is for the "established graduates" group. Mean tests support the idea that initial IQ for "established graduates" is statistically higher than for the other graduating categories at the $1 \%$ level. "Still in school" and "recent graduates" have initial IQ values that are statistically indistinguishable from each other. Column 3 of Table 1 shows that "established graduates" have the highest IQ inertia; i.e., lowest $\triangle \mathrm{IQ}$ values in absolute terms. Moreover, this group has seen a slight decline in IQ in recent times. On the other hand, "recent graduates" is the group with the highest recent

\footnotetext{
${ }^{9}$ The only exceptions are Rep. of Congo (1985), Gambia (1985), Niger (1985), Sierra
} Leone (1985), Yemen (1990), and Azerbaijan (1998). increase in IQ. Mean tests support the idea that $\Delta \mathrm{IQ}$ for "recent graduates" is statistically higher than for the other graduating categories at the $1 \%$ level. To sum up, "established graduates" have the highest initial IQ and show no major improvements over time. Both "still in school" and "recent graduates" share similar initial IQ conditions. However, the increase in IQ recently observed is much higher in "recent graduates" than the one observed in "still in school."

Although one thinks of institutions as slow-moving, they can change over time. Fig. 6 provides some examples of the within-country relation between IQ and cyclicality of fiscal policy by plotting for three different countries the correlation between government spending and GDP computed over a 20-year rolling window and the level of IQ. Panel A shows the case of Australia, an "established graduate." IQ levels have been consistently around 0.80 and fiscal policy has always been countercyclical. At the other extreme, Panel B shows the case of Venezuela, a "still in school" country. IQ levels have ranged between 0.24 and 0.58 and fiscal policy has been consistently procyclical. Panel $\mathrm{C}$ shows the case of Chile, a "recent graduate." The IQ increased from values close to 0.5 in the early 1980 s to more than 0.8 since the mid 2000s. In line with our arguments, fiscal policy shifted from being strongly procyclical - with values close to Venezuela's - to countercyclical.

Chile's experience is a good illustration of how a country with good IQ in the general sense of rule of law can help lock in countercyclical fiscal policy through specific budget institutions. Frankel (forthcoming) analyzes how Chile did it with the structural budget reforms of 2000 and 2006. Fiscal rules, such as euroland's Stability and Growth Pact, often accomplish little in themselves, because they are not necessarily enforced credibly. Rules can even worsen the general tendency of governments to make overly optimistic forecasts for economic growth and budget balance. ${ }^{10}$

\footnotetext{
${ }^{10}$ Frankel (2011).
} 
Table 1

Institutional quality statistics by graduating class.

\begin{tabular}{|c|c|c|c|}
\hline \multirow[t]{2}{*}{ Dependent variable is: } & IQ & IQ $^{\text {initial }}$ & $\Delta \mathrm{IQ}$ \\
\hline & (1) & $(2)$ & (3) \\
\hline \multicolumn{4}{|l|}{ Group means } \\
\hline Established graduate (EG) & 0.82 & 0.84 & -0.02 \\
\hline Still in school (SS) & 0.48 & 0.43 & 0.05 \\
\hline Recent graduate (RG) & 0.55 & 0.47 & 0.07 \\
\hline Back to School (BS) & 0.60 & 0.56 & 0.04 \\
\hline \multicolumn{4}{|l|}{ Mean tests ( $p$-value) } \\
\hline EG vs. SS & $1.9 \times 10^{-251}$ & $1.8 \times 10^{-12}$ & $2.3 \times 10^{-25}$ \\
\hline EG vs. RG & $2.1 \times 10^{-120}$ & $1.5 \times 10^{-6}$ & $7.7 \times 10^{-33}$ \\
\hline EG vs. BS & $1.6 \times 10^{-35}$ & 0.009 & $5.9 \times 10^{-20}$ \\
\hline SS vs. RG & $3.1 \times 10^{-19}$ & 0.346 & $1 \times 10^{-4}$ \\
\hline SS vs. BS & $5 \times 10^{-22}$ & 0.081 & 0.599 \\
\hline RG vs. BS & $4.5 \times 10^{-4}$ & 0.399 & 0.006 \\
\hline
\end{tabular}

Notes: Institutional quality is a normalized index that ranges between 0 (lowest institutional quality) and 1 (highest institutional quality). The index is calculated as the average of four components: investment profile, corruption, law and order, and bureaucratic quality. IQ refers to the current institutional quality value. IQ ${ }^{\text {initial }}$ refers to earliest IQ value available for each country; in most cases it corresponds to the 1984 value. The only exceptions are Rep. of Congo (1985), Gambia (1985), Niger (1985), Sierra Leone (1985), Yemen (1990), and Azerbaijan (1998). $\Delta \mathrm{IQ} \equiv \mathrm{IQ}-\mathrm{IQ}^{\text {initial }}$. The mean test is a $t$-test on the equality of means for two groups; the null hypothesis is that both groups have the same mean.

Source: International Country Risk Guide (ICRG).

Chile's key innovation was to give responsibility for forecasting to independent experts commissions, insulated from politicians' wishful thinking. Its approach could be emulated by others.
Finally, we use panel data regressions to exploit within-country variability as opposed to cross-country variability. Table 2, column 1 shows the estimates for $\alpha_{2}$ and $\alpha_{3}$ when estimating the following equation

$g_{i t}^{\mathrm{c}}=\alpha_{1}+\alpha_{2} y_{\mathrm{it}}^{\mathrm{c}}+\alpha_{3}\left(y_{i t}^{\mathrm{c}} \cdot \mathrm{IQ}_{i t}\right)+\alpha_{4} \mathrm{IQ}_{i t}+\eta_{i}+\varepsilon_{i t}$,

where $g^{\mathrm{c}}$ and $y^{\mathrm{c}}$ are the cyclical components of government spending and output. Our main result continues to hold: an increase in IQ reduces the degree of procyclicality. In line with our cross-country regression (see Fig. 5), we find an IQ threshold of 0.79 for graduation. Our results do not change when we allow each coefficient in Eq. (1) to vary by graduating class, as reported in Columns 2a-2d. The only case for which our main results are not supported is for "established graduates." This is mainly due to the small sample (15 countries) and, more importantly, to the small within-country variability of IQ described before for this set of countries.

We now decompose the variable IQ into its initial value $\mathrm{IQ}^{\text {initial }}$, which is constant over time, and $\Delta \mathrm{IQ}$ which varies over time. Table 2 , column 3 shows the estimates for $\alpha_{2}, \alpha_{3}$ and $\alpha_{4}$ when estimating the following equation

$$
\begin{aligned}
g_{i t}^{\mathrm{c}}= & \alpha_{1}+\alpha_{2} y_{i t}^{\mathrm{c}}+\alpha_{3}\left(y_{i t}^{\mathrm{c}} \cdot \mathrm{IQ}_{i t}^{\text {initial }}\right)+\alpha_{4}\left(y_{i t}^{\mathrm{c}} \cdot \Delta \mathrm{IQ}_{i t}\right)+\alpha_{5} \mathrm{IQ}_{i t}^{\text {initial }} \\
& +\alpha_{6} \Delta \mathrm{IQ}_{i t}+\eta_{i}+\varepsilon_{i t} .
\end{aligned}
$$

The underlying idea is to find out whether it is the highly inertial/ static component of IQ that matters for fiscal policy - à la Acemoglu et al. (2001) - or the dynamic component of IQ. For the whole sample (column 3) both factors, historical as well as more recent changes in IQ seem to matter. Our results do not change when we allow each

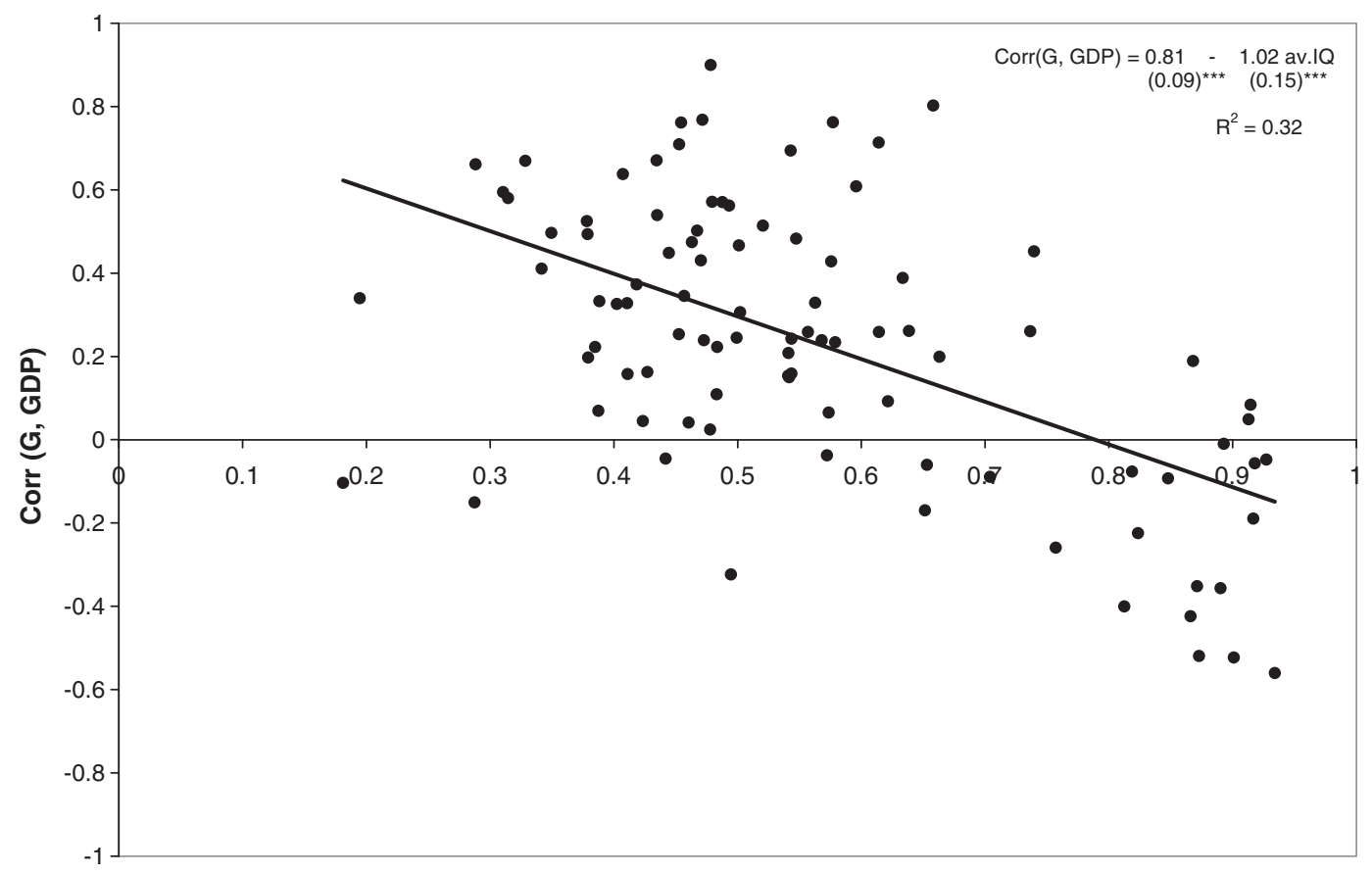

Average institutional quality (av. IQ)

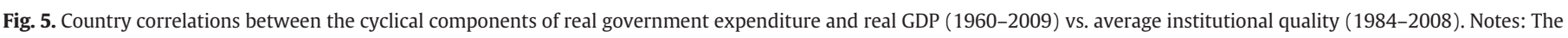

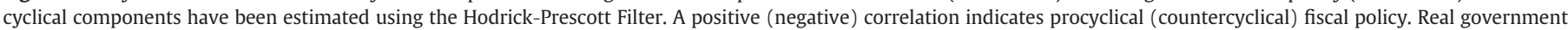

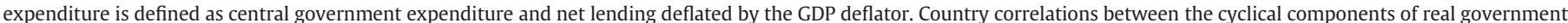

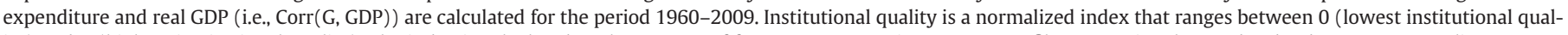

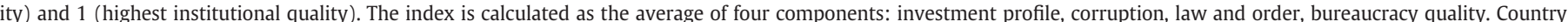

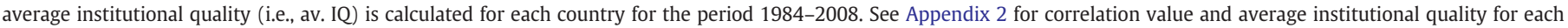
country.

Source: International Country Risk Guide (ICRG), World Economic Outlook and International Financial Statistics (IMF). 


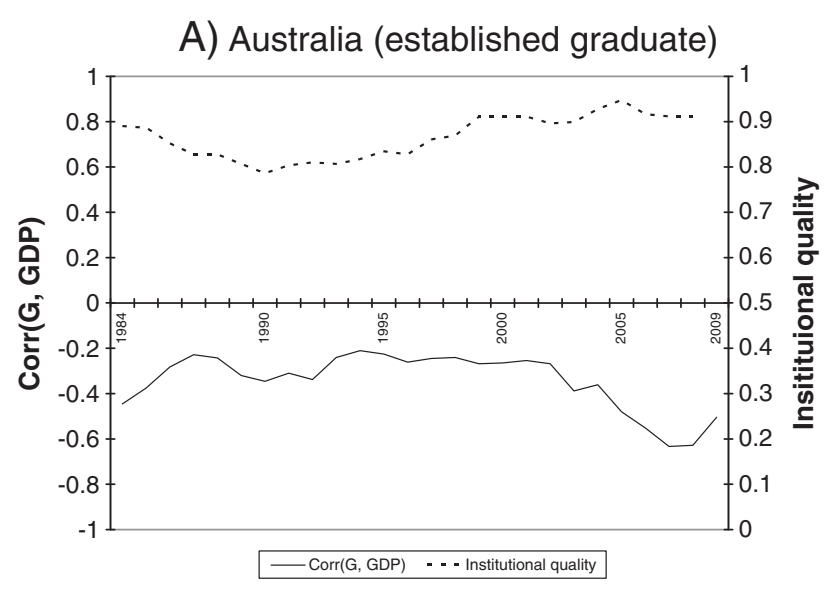

B) Venezuela (still in school)

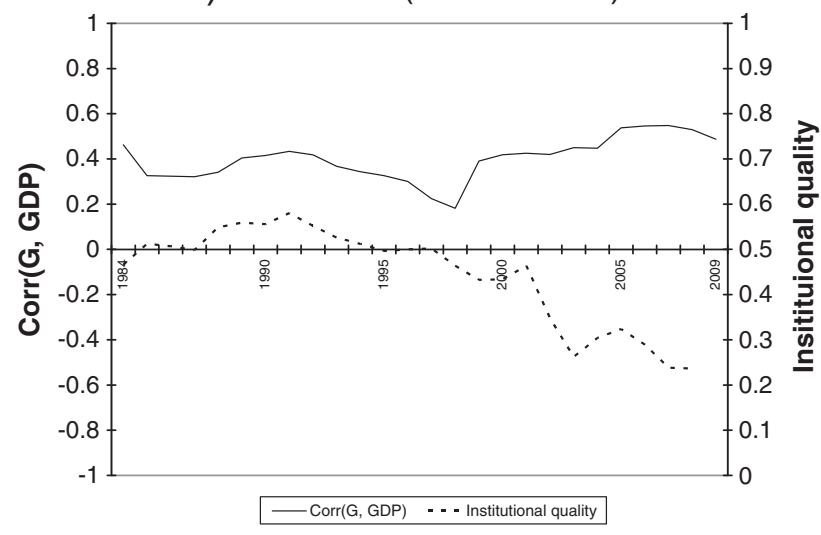

C) Chile (recent graduate)

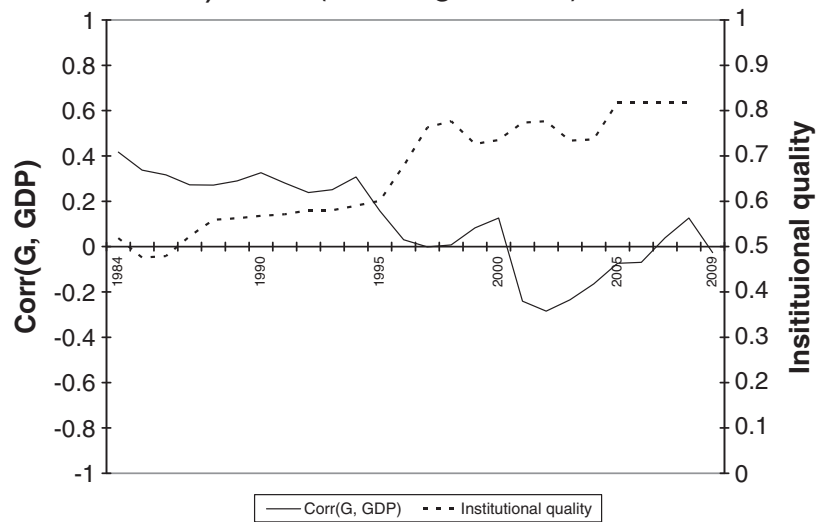

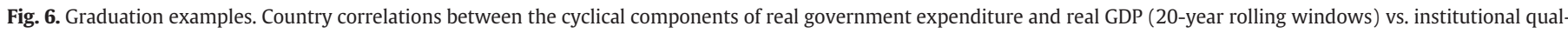

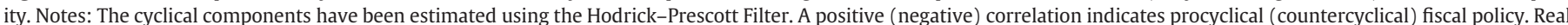

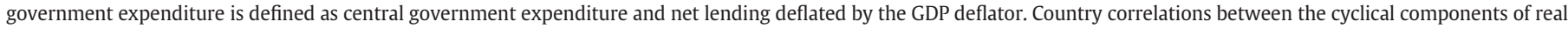

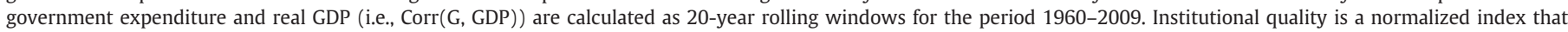

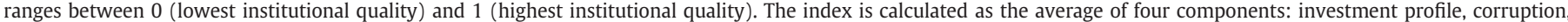

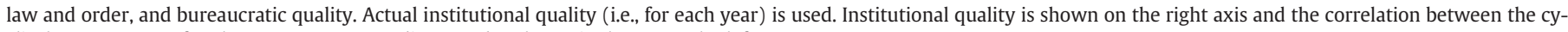
clical components of real government expenditure and real GDP is shown on the left.

Source: International Country Risk Guide (ICRG), World Economic Outlook and International Financial Statistics (IMF).

coefficient in Eq. (2) to vary by graduating class, as reported in Columns $4 \mathrm{a}-4 \mathrm{~d}$. Some interesting asymmetries emerge between the "still in school" and "recent graduate" categories. Column $4 \mathrm{~b}$ indicates that for the "still in school" group, historical factors dominate. This is consistent with very static IQ measures (compared to those of "recent graduates") during the last 25 years. Instead, for the "recent graduates" group, it is the more recent change in IQ (i.e., $\Delta \mathrm{IQ}$ ) that seems to be mainly driving the results. This suggests that changes in IQ are an important determinant of graduation.

Our analysis so far has suggested that IQ is an important determinant of procyclical fiscal policy. In particular, we have put forward the notion that about a third of developing countries have graduated from fiscal procyclicality due to important improvements in IQ during the last decade. Our analysis, however, could suffer from both omitted 
Table 2

Panel regressions. Dependent variable is the cyclical components of real government expenditure.

\begin{tabular}{|c|c|c|c|c|c|c|c|c|c|c|}
\hline & All & $\begin{array}{l}\text { Established } \\
\text { graduate (EG) }\end{array}$ & $\begin{array}{l}\text { Still in school } \\
\text { (SS) }\end{array}$ & $\begin{array}{l}\text { Recent } \\
\text { graduate (RG) }\end{array}$ & $\begin{array}{l}\text { Back to school } \\
\text { (BS) }\end{array}$ & All & $\begin{array}{l}\text { Established } \\
\text { graduate (EG) }\end{array}$ & $\begin{array}{l}\text { Still in school } \\
\text { (SS) }\end{array}$ & $\begin{array}{l}\text { Recent } \\
\text { graduate (RG) }\end{array}$ & $\begin{array}{l}\text { Back to school } \\
\text { (BS) }\end{array}$ \\
\hline & (1) & (2a) & (2b) & (2c) & (2d) & (3) & (4a) & $(4 \mathrm{~b})$ & (4c) & $(4 d)$ \\
\hline RGDP cycle & $\begin{array}{l}1.99^{* * *} \\
{[11.9]}\end{array}$ & $\begin{array}{l}-1.84 \\
{[-0.8]}\end{array}$ & $\begin{array}{l}1.55^{* * * *} \\
{[6.6]}\end{array}$ & $\begin{array}{l}1.04^{* *} \\
{[2.4]}\end{array}$ & $\begin{array}{l}2.95^{* * *} \\
{[6.6]}\end{array}$ & $\begin{array}{l}2.11^{* * * *} \\
{[12.1]}\end{array}$ & $\begin{array}{l}-1.73 \\
{[-0.8]}\end{array}$ & $\begin{array}{l}2.43^{* * *} \\
{[7.7]}\end{array}$ & $\begin{array}{l}1.27^{* * *} \\
{[2.8]}\end{array}$ & $\begin{array}{l}3.33^{* * *} \\
{[6.8]}\end{array}$ \\
\hline RGDP cycle ${ }^{\times}$IQ & $\begin{array}{l}-2.51^{* * *} \\
{[-7.4]}\end{array}$ & $\begin{array}{l}1.5 \\
{[0.5]}\end{array}$ & $\begin{array}{l}-1.19^{* *} \\
{[-2.3]}\end{array}$ & $\begin{array}{l}-1.34^{*} \\
{[-1.7]}\end{array}$ & $\begin{array}{l}-4.35^{* * *} \\
{[-4.6]}\end{array}$ & & & & & \\
\hline $\mathrm{RGDP}_{\text {cycle }}{ }^{\times} \mathrm{IQ}^{\text {initial }}$ & & & & & & $\begin{array}{l}-2.81^{* * *} \\
{[-7.7]}\end{array}$ & $\begin{array}{l}1.44 \\
{[0.5]}\end{array}$ & $\begin{array}{l}-3.25^{* * *} \\
{[-4.5]}\end{array}$ & $\begin{array}{l}-1.41^{*} \\
{[-1.8]}\end{array}$ & $\begin{array}{l}-4.43^{* * *} \\
{[-4.7]}\end{array}$ \\
\hline $\mathrm{R}^{2}$ & 0.10 & 0.12 & & & & 0.11 & 0.13 & & & \\
\hline Observations & 2273 & 2273 & & & & 2273 & 2273 & & & \\
\hline Countries & 94 & 94 & & & & 94 & 94 & & & \\
\hline
\end{tabular}

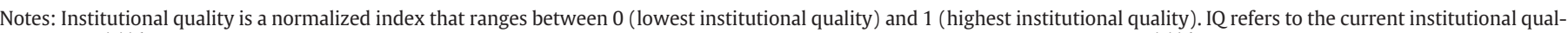

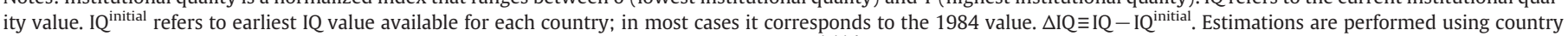
fixed-effects.. t-statistics are in square brackets. $R^{2}$ corresponds to within- $R^{2}$. Constant, IQ IQ ${ }^{\text {initial }}$, and $\Delta \mathrm{IQ}$ terms are not reported.

$\times, *, * *$ and ${ }^{* * *}$ indicate statistically significant at the $15 \%, 10 \%, 5 \%$ and $1 \%$ levels, respectively.

variables and endogeneity problems. The next two sections address these concerns.

\section{Other determinants of cyclicality}

While it seems natural to think that institutions affect the way in which fiscal policy is conducted, our findings so far could reflect the effect of omitted variables that are related to institutions. To address this concern, we include in our panel regressions three sets of control variables aimed at capturing alternative theories regarding cyclicality of fiscal policy.

First, we control for the degree of financial integration and depth. Among others, Gavin et al. (1996), Gavin and Perotti (1997), and Riascos and Vegh (2003) have argued that limited access to international capital markets (particularly in bad times) may limit the ability of governments to pursue countercyclical policies. In the same spirit, Caballero and Krishnamurthy (2004) have stressed the role of financial depth. We measure financial integration using the Chinn-Ito financial openness index (Chinn and Ito, 2006) and financial depth using liquid liabilities over GDP (Levine et al., 2000; Levine et al., 2010; Loayza and Ranciere, 2006). ${ }^{11}$ The panel data correlation between the Chinn-Ito financial openness index and IQ is 0.55 ; the panel data correlation between liquid liabilities and IQ is 0.53 . In Table 3, columns 2 and 3 show that more financial integration and depth are indeed associated with more countercyclicality/less procyclicality.

Second, we control for the variability of tax revenues - proxied by output variability - to account for the channel emphasized by Talvi and Vegh (2005) who argue that, in the presence of political distortions, the larger is the variability of tax revenues the more procyclical fiscal policy will be, as policymakers try to reduce the fiscal surplus in good times to prevent wasteful spending. We measure output variability using the square of the cyclical component of real GDP. ${ }^{12}$ Table 3, column 4 shows that, as in Lane (2003), higher output volatility does indeed increase the degree of procyclicality of fiscal policy.

Third, we address political economy arguments that stress common pool problems and fragmented policymaking (Velasco, 1997; Tornell and Lane, 1999). For these purposes, we use a measure of political checks and balances from the Database on Political institutions. ${ }^{13}$ Stronger checks and balances constrain politicians in their policy space. Politicians are also held more accountable to the

\footnotetext{
11 Similar results follow if private credit is used instead of liquid liabilities.

12 The panel data correlation between output variability and IQ is -0.19 .

13 The panel data correlation between checks and balances and IQ is 0.43 .
}

public, relative to an autocratic regime. In a more democratic regime, the expected returns to rent-seeking activities are lower. In Table 3, column 5 shows that stronger checks and balances decrease the degree of procyclicality of fiscal policy.

We also test whether debt-GDP ratios and foreign reserves holdings (in months of imports) matter for fiscal behavior over the business cycle. Recent low debt-GDP ratios and massive foreign reserves in emerging markets may have contributed to reduce those countries' default risk, allowing them to run countercyclical fiscal policies. In Table 3, columns 6 and 7 support these presumptions.

In Table 3, column 8 shows that even after accounting for standard determinants of fiscal cyclicality, institutional quality remains a strong determinant. There is no indication that problems related to omitted variables are driving our results.

\section{Addressing endogeneity}

This section addresses potential endogeneity problems. One could argue that the observed negative relationship between fiscal policy cyclicality and IQ may reflect the fact that countercyclical (procyclical) fiscal policies that tend to stabilize (destabilize) the economy might improve (worsen) institutional quality. That is to say, the causality may run from cyclicality of fiscal policies to institutional quality and not the other way around. For example, procyclical fiscal policies could increase the chances of governments running into debt sustainability problems during busts. These critical financing needs could then lead to expropriation, repudiation of contracts, and/or intervention in independent branches of governments such as the judiciary system or the central bank. Moreover, the turmoil typically associated with debt crises can exacerbate corruption in the political system thus weakening the foundations of an efficient and professional public administration. Similar arguments could also be made regarding the endogeneity of the control variables included in Section 4. For example, one could argue that it is procyclical fiscal policies that ultimately increase output volatility instead of the latter being the cause of procyclical fiscal policies.

We address such endogeneity concerns by instrumenting not only for IQ but also for the other six control variables. The literature on institutions has not found yet time-varying instrumental variables for the quality of institutions. Hence - and as is standard in this literature we rely on cross-country regressions (Acemoglu et al., 2001; Easterly and Levine, 2003; Glaeser et al., 2004; La Porta et al., 2008; Rodrik et al., 2004).

We follow Acemoglu et al.'s (2001) approach to instrument average IQ using European settlers' mortality and latitude (absolute value). They argue that European mortality rates (recorded among soldiers, bishops, 
Table 3

Panel regressions. Dependent variable is the cyclical components of real government expenditure.

\begin{tabular}{|c|c|c|c|c|c|c|c|c|}
\hline & $(1)$ & $(2)$ & (3) & (4) & (5) & $(6)$ & (7) & (8) \\
\hline RGDP cycle & $\begin{array}{l}2.00^{* * * *} \\
{[11.9]}\end{array}$ & $\begin{array}{l}0.86^{* * * *} \\
{[16.5]}\end{array}$ & $\begin{array}{l}1.26^{* * *} \\
{[13.4]}\end{array}$ & $\begin{array}{l}0.79 * * * \\
{[13.6]}\end{array}$ & $\begin{array}{l}1.11^{* * * *} \\
{[12.4]}\end{array}$ & $\begin{array}{l}0.49^{* * *} \\
{[6.3]}\end{array}$ & $\begin{array}{l}1.16^{* * * *} \\
{[15.0]}\end{array}$ & $\begin{array}{l}1.65^{* * * *} \\
{[4.4]}\end{array}$ \\
\hline RGDP cycle ${ }^{\times}$IQ & $\begin{array}{l}-2.52^{* * *} \\
{[-7.4]}\end{array}$ & & & & & & & $\begin{array}{l}-1.54^{* *} \\
{[-2.4]}\end{array}$ \\
\hline RGDP cycle ${ }^{\times}$Financial integration & & $\begin{array}{l}-0.13^{* * *} \\
{[-3.6]}\end{array}$ & & & & & & $\begin{array}{l}-0.07 \\
{[-1.2]}\end{array}$ \\
\hline RGDP cycle ${ }^{\times}$Financial depth & & & $\begin{array}{l}-1.10^{* * *} \\
{[-4.7]}\end{array}$ & & & & & $\begin{array}{l}-0.48 \\
{[-1.4]}\end{array}$ \\
\hline RGDP cycle ${ }^{\times}$Output volatility & & & & $\begin{array}{l}0.0004^{* * * *} \\
{[2.9]}\end{array}$ & & & & $\begin{array}{l}-0.0002 \\
{[-0.4]}\end{array}$ \\
\hline RGDP cycle ${ }^{\times}$Checks and balances & & & & & $\begin{array}{l}-0.12^{* * *} \\
{[-3.2]}\end{array}$ & & & $\begin{array}{l}-0.03 \\
{[-0.5]}\end{array}$ \\
\hline RGDP cycle ${ }^{\times}$Debt-GDP ratio & & & & & & $\begin{array}{l}0.30^{* * * *} \\
{[3.0]}\end{array}$ & & $\begin{array}{l}0.23 \\
{[1.3]}\end{array}$ \\
\hline RGDP cycle ${ }^{\times}$Foreign reserves & & & & & & & $\begin{array}{l}-0.06^{\text {**** }} \\
{[-4.3]}\end{array}$ & $\begin{array}{l}-0.03 \\
{[-0.9]}\end{array}$ \\
\hline $\mathrm{R}^{2}$ & 0.10 & 0.08 & 0.09 & 0.07 & 0.09 & 0.07 & 0.10 & 0.12 \\
\hline Observations & 2273 & 3412 & 2930 & 4089 & 3044 & 2701 & 2855 & 1278 \\
\hline Countries & 94 & 94 & 94 & 94 & 93 & 93 & 91 & 85 \\
\hline
\end{tabular}

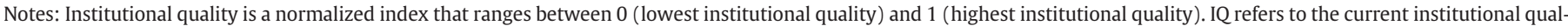

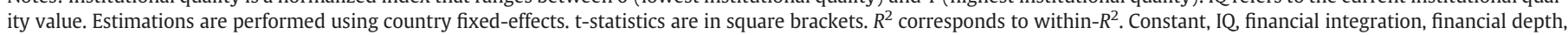
output volatility, checks and balances, debt-GDP ratio, and foreign reserves terms are not reported.

$\times,{ }^{*},{ }^{* *}$ and ${ }^{* * *}$ indicate statistically significant at the $15 \%, 10 \%, 5 \%$ and $1 \%$ levels, respectively.

and sailors stationed in the colonies) between the 17th and 19th centuries shaped, at least in part, the type of settlements and colonization strategy. In places where Europeans faced high mortality rates, they could not settle and they were more likely to set up worse (extractive) institutions. An archetypal example of this strategy is the Belgian colonization of the Congo. On the other hand, low mortality rates supported the development of important European settlements. In these "neo-Europe" states, the settlers tried to replicate European institutions, with emphasis on private property, and checks against government power. Primary examples include Australia, New Zealand, Canada, and the United States. Assuming high path dependence, early sound institutions would endure over time until the present.

We instrument financial integration and depth using legal origin (La Porta et al., 1997), output volatility using terms of trade volatility, and indebtedness using debt-GDP ratio in 1900 . We instrument checks and balances using constraints on the executive and democracy in 1900. The constraints on the executive in 1900 range from cases in which there are no regular limitations on the executive's actions to situations in which accountability groups have effective authority equal to or greater than the executive in most activities. Democracy in 1900 comprises several dimensions of political competitiveness.

It has been argued that, in light of the severe real dislocations resulting from international financial crises, many developing countries accumulate reserves as a form of self-insurance against capital flow volatility (Aizenman and Marion, 2003; Stiglitz, 2006). Following this rationale, we instrument foreign reserves using average frequency of currency crashes in mid 20th century; in particular, for the period 1940-1960.

Table 4 shows the cross-country correlations between all pairs of variables used in the analysis. With the exception of foreign reserves, the findings support our panel data regressions results reported above in that higher IQ financial integration and depth, and checks and balances are associated with countercyclicality, and higher output volatility and debt-GDP ratios are related to procyclicality. Instruments are also correlated as expected, both among themselves and with the variables they will be instrumenting for.

Table 5 shows, as in Lane (2003), OLS cross-country regressions where the dependent variable is the correlation between the cyclical components of real government expenditure and GDP. Columns 1 to 14 analyze the impact of each variable one at a time, both for the sample of 94 countries used so far in the paper as well as for the smaller sample of 52 countries that will be used in our instrumental variables regressions.
Two results are worth noting. First, with the exception of foreign reserves and debt-GDP ratios, cross-country regressions support our panel data regression findings. That is to say, higher IQ financial integration and depth, and checks and balances increase countercyclicality and output volatility increases procyclicality. Second, the results obtained for the sample of 94 countries also hold for the smaller sample of countries that will be used in our instrumental variables regressions. Columns 15 and 16 include all control variables together. As in our panel regressions, institutional quality is strongly significant in all cases.

Next, we address endogeneity problems. Table 6 shows how the proposed instruments relate to all seven cyclicality regressors. As shown by Acemoglu et al. (2001), European settlers' mortality is negatively related to IQ. The opposite is true for latitude. Similar results are obtained for financial integration and depth. Moreover, as suggested by La Porta et al. (1997), countries with British legal origin show higher development of their financial markets than those of French origins. Terms of trade volatility seems to be a good predictor of output volatility, and constraints on the executive and democracy in 1900 are found to be strongly related to recent checks and balances. Debt-GDP ratios in 1900 and currency crashes in mid 20th century are also strong predictors of debt-GDP ratios and foreign reserves, respectively. Indeed, the suggested instruments have very high predictive power overall: the $R^{2}$ ranges from 0.25 to 0.32 for foreign reserves and debt-GDP ratios to almost 0.7 for institutional quality.

Having checked that the proposed instruments seem to be good predictors for the variables they are instrumenting for, we proceed to estimate instrumental variables regressions. Table 7 shows the corresponding regressions. Columns 1 to 7 only instrument for IQ. Column 1 only includes IQ as regressor. Columns 2 to 7 sequencially add other determinants. In all cases we cannot reject the overidentification tests. The instruments are valid instruments (i.e., uncorrelated with the error term) and the excluded instruments are correctly excluded from the estimated equation. As suggested in Table 6, all instrumental variable regressions confirm that the excluded instruments are not weak instruments (i.e., they are strongly correlated with the endogenous regressors). We thus conclude that institutional quality remains a critical determinant of procyclicality even after accounting for possible endogeneity problems.

Finally, the regression shown in Table 7, column 8, corrects for the endogeneity of the rest of the right-hand variables. IQ remains 
Table 4

Cross-country correlations between economic, institutional, demographic and geographic variables.

\begin{tabular}{|c|c|c|c|c|c|c|c|c|c|c|c|c|c|c|c|c|c|c|}
\hline & $\begin{array}{l}\text { Corr(G, } \\
\text { GDP) }\end{array}$ & Av. IQ & $\begin{array}{l}\text { Financial } \\
\text { integration }\end{array}$ & $\begin{array}{l}\text { Financial } \\
\text { depth }\end{array}$ & $\begin{array}{l}\text { Output } \\
\text { volatility }\end{array}$ & $\begin{array}{l}\text { Checks } \\
\text { and } \\
\text { balances }\end{array}$ & $\begin{array}{l}\text { Debt-GDP } \\
\text { ratio }\end{array}$ & $\begin{array}{l}\text { Foreign } \\
\text { reserves }\end{array}$ & $\begin{array}{l}\text { Log } \\
\text { European } \\
\text { settler } \\
\text { mortality }\end{array}$ & Latitude & $\begin{array}{l}\text { British } \\
\text { colonial } \\
\text { dummy }\end{array}$ & $\begin{array}{l}\text { French } \\
\text { colonial } \\
\text { dummy }\end{array}$ & $\begin{array}{l}\text { French } \\
\text { legal } \\
\text { origin } \\
\text { dummy }\end{array}$ & $\begin{array}{l}\text { Democracy } \\
\text { in } 1900\end{array}$ & $\begin{array}{l}\text { Constraint on } \\
\text { executive } \\
\text { in } 1900\end{array}$ & $\begin{array}{l}\text { Terms } \\
\text { of trade } \\
\text { volatility }\end{array}$ & $\begin{array}{l}\text { Debt-GDP } \\
\text { ratio in } \\
1900\end{array}$ & $\begin{array}{l}\text { Currency } \\
\text { crashes } \\
\text { in mid } \\
\text { 20th } \\
\text { century }\end{array}$ \\
\hline Corr(G, GDP) & 1 & & & & & & & & & & & & & & & & & \\
\hline Av. IQ & -0.49 & 1 & & & & & & & & & & & & & & & & \\
\hline Financial integration & -0.35 & 0.41 & 1 & & & & & & & & & & & & & & & \\
\hline Financial depth & -0.34 & 0.60 & 0.38 & 1 & & & & & & & & & & & & & & \\
\hline Output volatility & 0.49 & -0.37 & -0.22 & -0.44 & 1 & & & & & & & & & & & & & \\
\hline Checks and balances & -0.35 & 0.49 & 0.36 & 0.33 & -0.31 & 1 & & & & & & & & & & & & \\
\hline Debt-GDP ratio & 0.11 & -0.15 & -0.06 & -0.14 & 0.24 & -0.18 & 1 & & & & & & & & & & & \\
\hline Foreign reserves & 0.07 & 0.02 & -0.06 & 0.19 & 0.04 & 0.28 & -0.29 & 1 & & & & & & & & & & \\
\hline Log European settler mortality & 0.47 & -0.61 & -0.36 & -0.63 & 0.53 & -0.46 & 0.37 & -0.19 & 1 & & & & & & & & & \\
\hline Latitude & -0.36 & 0.54 & 0.24 & 0.50 & -0.32 & 0.20 & -0.21 & 0.11 & -0.52 & 1 & & & & & & & & \\
\hline British colonial dummy & -0.43 & 0.36 & 0.10 & 0.47 & -0.33 & 0.34 & -0.08 & -0.07 & -0.27 & 0.19 & 1 & & & & & & & \\
\hline French colonial dummy & 0.41 & -0.25 & -0.33 & -0.15 & 0.19 & -0.41 & 0.23 & -0.22 & 0.38 & -0.02 & -0.44 & 1 & & & & & & \\
\hline French legal origin dummy & 0.43 & -0.36 & -0.07 & -0.36 & 0.34 & -0.32 & 0.09 & 0.12 & 0.23 & -0.13 & -0.92 & 0.44 & 1 & & & & & \\
\hline Democracy in 1900 & -0.53 & 0.70 & 0.43 & 0.42 & -0.34 & 0.36 & -0.18 & 0.04 & -0.58 & 0.52 & 0.20 & -0.30 & -0.11 & 1 & & & & \\
\hline Constraint on executive in 1900 & -0.52 & 0.65 & 0.33 & 0.38 & -0.31 & 0.36 & -0.25 & 0.10 & -0.56 & 0.46 & 0.14 & -0.31 & -0.03 & 0.95 & 1 & & & \\
\hline Terms of trade volatility & 0.20 & -0.40 & -0.35 & -0.47 & 0.37 & -0.40 & 0.28 & 0.08 & 0.43 & -0.42 & 0.00 & 0.03 & -0.06 & -0.34 & -0.32 & 1 & & \\
\hline Debt-GDP ratio in 1900 & 0.23 & -0.09 & -0.13 & -0.12 & 0.16 & -0.31 & 0.35 & -0.13 & 0.16 & -0.02 & -0.39 & 0.38 & 0.39 & -0.04 & -0.07 & 0.02 & 1 & \\
\hline Currency crashes in mid 20th century & 0.14 & 0.00 & -0.19 & -0.18 & 0.23 & -0.22 & -0.04 & 0.24 & 0.06 & 0.15 & -0.43 & 0.20 & 0.43 & -0.06 & 0.02 & -0.09 & 0.15 & 1 \\
\hline
\end{tabular}


Table 5

Cross-country regressions. Dependent variable is the correlation between the cyclical components of real government expenditure and GDP.

\begin{tabular}{|c|c|c|c|c|c|c|c|c|c|c|c|c|c|c|c|c|}
\hline & $\begin{array}{l}\text { Whole } \\
\text { sample }\end{array}$ & $\begin{array}{l}\text { IV } \\
\text { sample }\end{array}$ & $\begin{array}{l}\text { Whole } \\
\text { sample }\end{array}$ & $\begin{array}{l}\text { IV } \\
\text { sample }\end{array}$ & $\begin{array}{l}\text { Whole } \\
\text { sample }\end{array}$ & $\begin{array}{l}\text { IV } \\
\text { sample }\end{array}$ & $\begin{array}{l}\text { Whole } \\
\text { sample }\end{array}$ & $\begin{array}{l}\text { IV } \\
\text { sample }\end{array}$ & $\begin{array}{l}\text { Whole } \\
\text { sample }\end{array}$ & $\begin{array}{l}\text { IV } \\
\text { sample }\end{array}$ & $\begin{array}{l}\text { Whole } \\
\text { sample }\end{array}$ & $\begin{array}{l}\text { IV } \\
\text { sample }\end{array}$ & $\begin{array}{l}\text { Whole } \\
\text { sample }\end{array}$ & $\begin{array}{l}\text { IV } \\
\text { sample }\end{array}$ & $\begin{array}{l}\text { Whole } \\
\text { sample }\end{array}$ & $\begin{array}{l}\text { IV } \\
\text { sample }\end{array}$ \\
\hline & (1) & (2) & (3) & (4) & (5) & (6) & (7) & (8) & (9) & $(10)$ & $(11)$ & $(12)$ & (13) & (14) & (15) & $(16)$ \\
\hline Av. IQ & $\begin{array}{l}-1.02^{* * * *} \\
{[-6.6]}\end{array}$ & $\begin{array}{l}-0.90^{* * * *} \\
{[-4.0]}\end{array}$ & & & & & & & & & & & & & $\begin{array}{l}-0.49^{* *} \\
{[-2.1]}\end{array}$ & $\begin{array}{l}-0.57^{*} \\
{[-1.9]}\end{array}$ \\
\hline $\begin{array}{l}\text { Financial } \\
\text { integration }\end{array}$ & & & $\begin{array}{l}-0.10^{* * *} \\
{[-4.2]}\end{array}$ & $\begin{array}{l}-0.09^{* *} \\
{[-2.7]}\end{array}$ & & & & & & & & & & & $\begin{array}{l}-0.03 \\
{[-1.1]}\end{array}$ & $\begin{array}{l}-0.03 \\
{[-1.0]}\end{array}$ \\
\hline Financial depth & & & & & $\begin{array}{l}-0.43^{* * *} \\
{[-4.0]}\end{array}$ & $\begin{array}{l}-0.59^{* *} \\
{[-2.6]}\end{array}$ & & & & & & & & & $\begin{array}{l}-0.16 \\
{[-1.1]}\end{array}$ & $\begin{array}{l}0.11 \\
{[0.4]}\end{array}$ \\
\hline $\begin{array}{l}\text { Output } \\
\text { volatility }\end{array}$ & & & & & & & $\begin{array}{l}0.08^{* * *} \\
{[6.9]}\end{array}$ & $\begin{array}{l}0.08^{* * *} \\
{[3.9]}\end{array}$ & & & & & & & $\begin{array}{l}0.05^{* * *} \\
{[3.7]}\end{array}$ & $\begin{array}{l}0.05^{* *} \\
{[2.4]}\end{array}$ \\
\hline $\begin{array}{c}\text { Checks and } \\
\text { balances }\end{array}$ & & & & & & & & & $\begin{array}{l}-0.12^{* * *} \\
{[-5.5]}\end{array}$ & $\begin{array}{l}-0.09^{* *} \\
{[-2.7]}\end{array}$ & & & & & $\begin{array}{l}-0.02 \\
{[-0.9]}\end{array}$ & $\begin{array}{l}-0.02 \\
{[-0.6]}\end{array}$ \\
\hline $\begin{array}{l}\text { Debt-GDP } \\
\text { ratio }\end{array}$ & & & & & & & & & & & $\begin{array}{l}0.08 \\
{[1.1]}\end{array}$ & $\begin{array}{l}0.06 \\
{[0.8]}\end{array}$ & & & $\begin{array}{l}0.01 \\
{[0.1]}\end{array}$ & $\begin{array}{l}-0.01 \\
{[-0.1]}\end{array}$ \\
\hline $\begin{array}{l}\text { Foreign } \\
\text { reserves }\end{array}$ & & & & & & & & & & & & & $\begin{array}{l}0.01 \\
{[1.0]}\end{array}$ & $\begin{array}{l}0.01 \\
{[0.5]}\end{array}$ & $\begin{array}{l}0.01 \\
{[0.5]}\end{array}$ & $\begin{array}{l}0.01 \\
{[0.4]}\end{array}$ \\
\hline$R^{2}$ & 0.32 & 0.24 & 0.16 & 0.12 & 0.15 & 0.12 & 0.34 & 0.24 & 0.25 & 0.12 & 0.01 & 0.01 & 0.01 & 0.01 & 0.53 & 0.38 \\
\hline Observations & 94 & 52 & 94 & 52 & 94 & 52 & 94 & 52 & 93 & 52 & 94 & 52 & 91 & 52 & 90 & 52 \\
\hline
\end{tabular}

Notes: See Appendix 1 for definition and source of variables. t-statistics are in square brackets. Constant term is not reported.

$\times{ }^{*}, * *$ and ${ }^{* * *}$ indicate statistically significant at the $15 \%, 10 \%, 5 \%$ and $1 \%$ levels, respectively.

strongly negatively related to the cyclicality of fiscal policy confirming that there is a strong causal link running from better institutions to less procyclical/more countercyclical fiscal policy.

\section{Conclusions}

We have shown that, over the past decade, a substantial number of emerging and developing countries have "graduated" from fiscal procyclicality in the sense of being able to shift from procyclical to countercyclical fiscal policy. Further, we have argued that a critical determinant of whether a country has been able to graduate or not is institutional quality. We have formally linked the degree of fiscal procyclicality to institutional quality and shown that, even when correcting for endogeneity and other determinants, there is a strong causal link running from better institutions to less procyclical/more countercyclical fiscal policy.

While institutional change is certainly not easy and often occurs only slowly over time, the payoff in terms of enabling countries to escape the fiscal procyclicality trap can be large. Chile is perhaps the best example of a country that has succeeded in developing stronger fiscal institutions over time and, as result, has been able to conduct countercyclical fiscal policy over the last decade. This graduation process, however, can be a long and arduous road and does require clear economic leadership and a strong political consensus.

\section{Appendix 1. Definition of variables and sources}

\section{A. Gross Domestic Product}

World Economic Outlook (WEO-IMF) and International Financial Statistics (IFS-IMF) were the main data sources. Series NGDP (gross domestic product, current prices) for WEO and 99B for IFS-IMF. For Azerbaijan, Bahrain, Kuwait, Libya, Qatar, and United Arab Emirates data were provided by the Middle East Department at the IMF. Data period covers 1960-2009.

\section{B. Government expenditure}

World Economic Outlook (WEO-IMF) was the main data source, series GCENL (central government, total expenditure and net lending). Due to unavailability of central government data, general government data were used for Azerbaijan, Ecuador, Kuwait, Libya, Qatar, and United Arab Emirates. For Azerbaijan, Bahrain, Kuwait, Libya, Qatar, and United Arab Emirates data were provided by the Middle East Department at the IMF. For Brazil data were from Instituto de Pesquisa Econômica Aplicada (IPEA). Data period covers 1960-2009.

\section{C. GDP deflator}

World Economic Outlook (WEO-IMF) and International Financial Statistics (IFS-IMF) were the main data sources. Series NGDP_D (gross domestic product deflator) for WEO-IMF and 99BIP for IFS-IMF. For Azerbaijan, Bahrain, Kuwait, Libya, Qatar, and United Arab Emirates data were provided by the Middle East Department at the IMF. Data period covers 1960-2009.

\section{D. Financial depth}

Measured as liquid liabilities over GDP. Loayza and Ranciere (2006) and Levine et al. (2010) were the main data sources. Data period covers 1960-2006.

\section{E. Financial integration}

Measured with the Chinn-Ito financial openness index; Chinn and Ito (2006). Such index measures a country's degree of capital account openness. Data period covers 1970-2009.

\section{F. Debt-GDP ratio and Debt-GDP ratio in 1900}

World Economic Outlook (WEO-IMF), World Development Indicators (WDI-World Bank), and Reinhart and Rogoff (2011) were the 
Table 6

Cross-country regressions. Dependent variables are Av. IQ Financial integration, Financial depth, Output volatility, Checks and balances, Debt-GDP ratio, and Foreign reserves.

\begin{tabular}{|c|c|c|c|c|c|c|c|c|c|c|c|c|c|c|c|c|c|c|}
\hline & \multicolumn{9}{|c|}{ Panel A. Dependent variable is Av. IQ } & \multicolumn{9}{|c|}{ Panel B. Dependent variable is Financial integration } \\
\hline & (1) & (2) & (3) & (4) & (5) & (6) & (7) & (8) & (9) & (1) & (2) & (3) & (4) & (5) & (6) & (7) & (8) & (9) \\
\hline Log European settler mortality & $\begin{array}{l}-0.07^{* * *} \\
{[-5.5]}\end{array}$ & & & & & & & & $\begin{array}{l}-0.02^{\times} \\
{[-1.6]}\end{array}$ & $\begin{array}{l}-0.31^{* * *} \\
{[-2.7]}\end{array}$ & & & & & & & & $\begin{array}{l}-0.02 \\
{[-0.1]}\end{array}$ \\
\hline Latitude & & $\begin{array}{l}0.59^{* * *} \\
{[4.6]}\end{array}$ & & & & & & & $\begin{array}{l}0.07 \\
{[0.5]}\end{array}$ & & $\begin{array}{l}1.89^{*} \\
{[1.7]}\end{array}$ & & & & & & & $\begin{array}{l}0.20 \\
{[0.2]}\end{array}$ \\
\hline British colonial dummy & & & $\begin{array}{l}0.06 \\
{[0.5]}\end{array}$ & & & & & & $\begin{array}{l}-0.07 \\
{[-1.0]}\end{array}$ & & & $\begin{array}{l}0.25 \\
{[0.3]}\end{array}$ & & & & & & $\begin{array}{l}-0.15 \\
{[-0.2]}\end{array}$ \\
\hline French colonial dummy & & & $\begin{array}{l}-0.04 \\
{[-0.7]}\end{array}$ & & & & & & $\begin{array}{l}0.04 \\
{[1.0]}\end{array}$ & & & $\begin{array}{l}-0.89^{* *} \\
{[-2.4]}\end{array}$ & & & & & & $\begin{array}{l}-0.74^{*} \\
{[-1.9]}\end{array}$ \\
\hline French legal origin dummy & & & $\begin{array}{l}-0.04 \\
{[-0.4]}\end{array}$ & & & & & & $\begin{array}{l}-0.19^{* *} \\
{[-2.7]}\end{array}$ & & & $\begin{array}{l}0.41 \\
{[0.5]}\end{array}$ & & & & & & $\begin{array}{l}0.45 \\
{[0.6]}\end{array}$ \\
\hline Democracy in 1900 & & & & $\begin{array}{l}0.03^{* * *} \\
{[6.9]}\end{array}$ & & & & & $\begin{array}{l}0.02 \\
{[1.0]}\end{array}$ & & & & $\begin{array}{l}0.15^{* * *} \\
{[3.4]}\end{array}$ & & & & & $\begin{array}{l}0.40^{* *} \\
{[2.6]}\end{array}$ \\
\hline Constraint on executive in 1900 & & & & & $\begin{array}{l}0.05^{* * *} \\
{[6.1]}\end{array}$ & & & & $\begin{array}{l}0.01 \\
{[0.7]}\end{array}$ & & & & & $\begin{array}{l}0.17^{* *} \\
{[2.5]}\end{array}$ & & & & $\begin{array}{l}-0.48^{* *} \\
{[-2.2]}\end{array}$ \\
\hline Terms of trade volatility & & & & & & $\begin{array}{l}-0.01^{* * *} \\
{[-3.1]}\end{array}$ & & & $\begin{array}{l}-0.01 \\
{[-1.3]}\end{array}$ & & & & & & $\begin{array}{l}-0.10^{* *} \\
{[-2.6]}\end{array}$ & & & $\begin{array}{l}-0.06^{\times} \\
{[-1.6]}\end{array}$ \\
\hline Debt-GDP ratio in 1900 & & & & & & & $\begin{array}{l}-0.03 \\
{[-0.6]}\end{array}$ & & $\begin{array}{l}0.02 \\
{[0.6]}\end{array}$ & & & & & & & $\begin{array}{l}-0.35 \\
{[-0.9]}\end{array}$ & & $\begin{array}{l}-0.30 \\
{[-0.8]}\end{array}$ \\
\hline Currency crashes in mid 20th century & & & & & & & & $\begin{array}{l}0.002 \\
{[0.01]}\end{array}$ & $\begin{array}{l}0.16 \\
{[1.4]}\end{array}$ & & & & & & & & $\begin{array}{l}-1.55 \\
{[-1.4]}\end{array}$ & $\begin{array}{l}-1.31 \\
{[-1.1]}\end{array}$ \\
\hline$R^{2}$ & 0.38 & 0.30 & 0.15 & 0.49 & 0.43 & 0.16 & 0.01 & 0.01 & 0.69 & 0.13 & 0.06 & 0.12 & 0.19 & 0.11 & 0.12 & 0.02 & 0.04 & 0.40 \\
\hline \multirow[t]{3}{*}{ Observations } & 52 & 52 & 52 & 52 & 52 & 52 & 52 & 52 & 52 & 52 & 52 & 52 & 52 & 52 & 52 & 52 & 52 & 52 \\
\hline & \multicolumn{9}{|c|}{ Panel C. Dependent variable is Financial depth } & \multicolumn{9}{|c|}{ Panel D. Dependent variable is Output volatility } \\
\hline & $(1)$ & $(2)$ & $(3)$ & $(4)$ & $(5)$ & $(6)$ & $(7)$ & (8) & (9) & $(1)$ & $(2)$ & $(3)$ & (4) & (5) & (6) & $(7)$ & (8) & (9) \\
\hline Log European settler mortality & $\begin{array}{l}-0.08^{* * *} \\
{[-5.7]}\end{array}$ & & & & & & & & $\begin{array}{l}-0.06^{* * *} \\
{[-3.2]}\end{array}$ & $\begin{array}{l}0.74^{* * * *} \\
{[4.4]}\end{array}$ & & & & & & & & $\begin{array}{l}0.54^{* *} \\
{[2.2]}\end{array}$ \\
\hline Latitude & & $\begin{array}{l}0.57^{* * *} \\
{[4.1]}\end{array}$ & & & & & & & $\begin{array}{l}0.12 \\
{[0.8]}\end{array}$ & & $\begin{array}{l}-4.15^{* *} \\
{[-2.4]}\end{array}$ & & & & & & & $\begin{array}{l}-0.32 \\
{[-0.1]}\end{array}$ \\
\hline British colonial dummy & & & $\begin{array}{l}0.29^{* * *} \\
{[2.9]}\end{array}$ & & & & & & $\begin{array}{l}0.20^{* *} \\
{[2.4]}\end{array}$ & & & $\begin{array}{l}-0.43 \\
{[-0.3]}\end{array}$ & & & & & & $\begin{array}{l}0.70 \\
{[0.6]}\end{array}$ \\
\hline French colonial dummy & & & 0.02 & & & & & & $0.07^{\times}$ & & & 0.17 & & & & & & -0.53 \\
\hline French legal origin dummy & & & $\begin{array}{l}{[0.4]} \\
0.14 \\
{[1.4]}\end{array}$ & & & & & & $\begin{array}{l}{[1.5]} \\
0.08 \\
{[0.9]}\end{array}$ & & & $\begin{array}{l}{[0.3]} \\
0.75 \\
{[0.6]}\end{array}$ & & & & & & $\begin{array}{l}{[-0.9]} \\
1.55 \\
{[1.3]}\end{array}$ \\
\hline Democracy in 1900 & & & & $\begin{array}{l}0.02^{* * *} \\
{[3.3]}\end{array}$ & & & & & $\begin{array}{l}0.0001 \\
{[0.01]}\end{array}$ & & & & $\begin{array}{l}-0.19^{* *} \\
{[-2.6]}\end{array}$ & & & & & $\begin{array}{l}0.10 \\
{[0.4]}\end{array}$ \\
\hline Constraint on executive in 1900 & & & & & $\begin{array}{l}0.03^{* * *} \\
{[2.9]}\end{array}$ & & & & $\begin{array}{l}-0.001 \\
{[-0.04]}\end{array}$ & & & & & $\begin{array}{l}-0.26^{* *} \\
{[-2.3]}\end{array}$ & & & & $\begin{array}{l}-0.20 \\
{[-0.6]}\end{array}$ \\
\hline Terms of trade volatility & & & & & & $\begin{array}{l}-0.02^{* * *} \\
{[-3.7]}\end{array}$ & & & $\begin{array}{l}-0.01^{* *} \\
{[-2.0]}\end{array}$ & & & & & & $\begin{array}{l}0.17^{* * *} \\
{[2.8]}\end{array}$ & & & $\begin{array}{l}0.10^{\times} \\
{[1.6]}\end{array}$ \\
\hline Debt-GDP ratio in 1900 & & & & & & & $\begin{array}{l}-0.05 \\
{[-0.9]}\end{array}$ & & $\begin{array}{l}0.01 \\
{[0.4]}\end{array}$ & & & & & & & $\begin{array}{l}0.70 \\
{[1.2]}\end{array}$ & & $\begin{array}{l}0.08 \\
{[0.1]}\end{array}$ \\
\hline Currency crashes in mid 20th century & & & & & & & & $\begin{array}{l}-0.22 \\
{[-1.3]}\end{array}$ & $\begin{array}{l}-0.4] \\
-0.09 \\
{[-0.6]}\end{array}$ & & & & & & & & $\begin{array}{l}3.09^{*} \\
{[1.7]}\end{array}$ & $\begin{array}{l}2.28 \\
{[1.2]}\end{array}$ \\
\hline$R^{2}$ & 0.40 & 0.25 & 0.25 & 0.18 & 0.14 & 0.22 & 0.02 & 0.03 & 0.62 & 0.28 & 0.10 & 0.12 & 0.12 & 0.10 & 0.14 & 0.03 & 0.05 & 0.41 \\
\hline Observations & 52 & 52 & 52 & 52 & 52 & 52 & 52 & 52 & 52 & 52 & 52 & 52 & 52 & 52 & 52 & 52 & 52 & 52 \\
\hline
\end{tabular}


Table 6 (continued)

\begin{tabular}{|c|c|c|c|c|c|c|c|c|c|c|c|c|c|c|c|c|c|c|}
\hline & \multicolumn{9}{|c|}{ Panel E. Dependent variable is Checks and balances } & \multicolumn{9}{|c|}{ Panel F. Dependent variable is Debt-GDP ratio } \\
\hline & (1) & (2) & (3) & (4) & (5) & (6) & (7) & (8) & (9) & (1) & (2) & (3) & (4) & (5) & (6) & (7) & (8) & (9) \\
\hline Log European settler mortality & $\begin{array}{l}-0.41^{* * *} \\
{[-3.7]}\end{array}$ & & & & & & & & $\begin{array}{l}-0.15 \\
{[-1.0]}\end{array}$ & $\begin{array}{l}0.15^{* * * *} \\
{[2.8]}\end{array}$ & & & & & & & & $\begin{array}{l}0.10 \\
{[1.3]}\end{array}$ \\
\hline Latitude & & $\begin{array}{l}1.61 \\
{[1.4]}\end{array}$ & & & & & & & $\begin{array}{l}-0.77 \\
{[-0.6]}\end{array}$ & & $\begin{array}{l}-0.77^{\times} \\
{[-1.5]}\end{array}$ & & & & & & & $\begin{array}{l}-0.39 \\
{[-0.6]}\end{array}$ \\
\hline British colonial dummy & & & $\begin{array}{l}0.40 \\
{[0.5]}\end{array}$ & & & & & & $\begin{array}{l}-0.24 \\
{[-0.3]}\end{array}$ & & & $\begin{array}{l}0.09 \\
{[0.3]}\end{array}$ & & & & & & $\begin{array}{l}0.39 \\
{[1.1]}\end{array}$ \\
\hline French colonial dummy & & & $\begin{array}{l}-0.82^{* *} \\
{[-2.2]}\end{array}$ & & & & & & $\begin{array}{l}-0.38 \\
{[-1.0]}\end{array}$ & & & $\begin{array}{l}0.28^{\times} \\
{[1.6]}\end{array}$ & & & & & & $\begin{array}{l}0.07 \\
{[0.4]}\end{array}$ \\
\hline French legal origin dummy & & & $\begin{array}{l}-0.06 \\
{[-0.1]}\end{array}$ & & & & & & $\begin{array}{l}-0.58 \\
{[-0.8]}\end{array}$ & & & $\begin{array}{l}0.07 \\
{[0.2]}\end{array}$ & & & & & & $\begin{array}{l}0.30 \\
{[0.8]}\end{array}$ \\
\hline Democracy in 1900 & & & & $\begin{array}{l}0.13^{* * *} \\
{[2.8]}\end{array}$ & & & & & $\begin{array}{l}-0.04 \\
{[-0.3]}\end{array}$ & & & & $\begin{array}{l}-0.03 \\
{[-1.3]}\end{array}$ & & & & & $\begin{array}{l}0.12^{\times} \\
{[1.6]}\end{array}$ \\
\hline Constraint on executive in 1900 & & & & & $\begin{array}{l}0.19^{* * *} \\
{[2.7]}\end{array}$ & & & & $\begin{array}{l}0.14 \\
{[0.7]}\end{array}$ & & & & & $\begin{array}{l}-0.06^{*} \\
{[-1.8]}\end{array}$ & & & & $\begin{array}{l}-0.17^{\times} \\
{[-1.6]}\end{array}$ \\
\hline Terms of trade volatility & & & & & & $\begin{array}{l}-0.12^{* * *} \\
{[-3.1]}\end{array}$ & & & $\begin{array}{l}-0.10^{* *} \\
{[-2.5]}\end{array}$ & & & & & & $\begin{array}{l}0.03^{* *} \\
{[2.0]}\end{array}$ & & & $\begin{array}{l}0.02 \\
{[1.1]}\end{array}$ \\
\hline Debt-GDP ratio in 1900 & & & & & & & $\begin{array}{l}-0.86^{* *} \\
{[-2.3]}\end{array}$ & & $\begin{array}{l}-0.37 \\
{[-1.0]}\end{array}$ & & & & & & & $\begin{array}{l}0.43^{* *} \\
{[2.7]}\end{array}$ & & $\begin{array}{l}0.36^{*} \\
{[2.0]}\end{array}$ \\
\hline Currency crashes in mid 20th century & & & & & & & & $\begin{array}{l}-1.87^{\times} \\
{[-1.6]}\end{array}$ & $\begin{array}{l}-1.07 \\
{[-0.9]}\end{array}$ & & & & & & & & $\begin{array}{l}-0.13 \\
{[-0.3]}\end{array}$ & $\begin{array}{l}0.09 \\
{[0.2]}\end{array}$ \\
\hline$R^{2}$ & 0.21 & 0.04 & 0.20 & 0.13 & 0.13 & 0.16 & 0.10 & 0.05 & 0.43 & 0.14 & 0.05 & 0.06 & 0.03 & 0.06 & 0.08 & 0.13 & 0.01 & 0.32 \\
\hline \multirow[t]{3}{*}{ Observations } & 52 & 52 & 52 & 52 & 52 & 52 & 52 & 52 & 52 & 52 & 52 & 52 & 52 & 52 & 52 & 52 & 52 & 52 \\
\hline & & \multicolumn{17}{|c|}{ Panel G. Dependent variable is Foreign reserves } \\
\hline & & $(1)$ & & $(2)$ & & (3) & & (4) & & (5) & & (6) & & (7) & & (8) & & (9) \\
\hline Log European settler mortality & & $\begin{array}{l}-0.34 \\
{[-1.4]}\end{array}$ & & & & & & & & & & & & & & & & $\begin{array}{l}-0.45 \\
{[-1.3]}\end{array}$ \\
\hline Latitude & & & & $\begin{array}{l}1.79 \\
{[0.8]}\end{array}$ & & & & & & & & & & & & & & $\begin{array}{l}2.53 \\
{[0.8]}\end{array}$ \\
\hline British colonial dummy & & & & & & $\begin{array}{l}0.87 \\
{[0.6]}\end{array}$ & & & & & & & & & & & & $\begin{array}{l}1.01 \\
{[0.6]}\end{array}$ \\
\hline French colonial dummy & & & & & & $\begin{array}{l}-1.64^{* *} \\
{[-2.1]}\end{array}$ & & & & & & & & & & & & $\begin{array}{l}-1.41^{\times} \\
{[-1.6]}\end{array}$ \\
\hline French legal origin dummy & & & & & & $\begin{array}{l}1.99 \\
{[1.3]}\end{array}$ & & & & & & & & & & & & $\begin{array}{l}2.09 \\
{[1.2]}\end{array}$ \\
\hline Democracy in 1900 & & & & & & & & $\begin{array}{l}0.03 \\
{[0.3]}\end{array}$ & & & & & & & & & & $\begin{array}{l}-0.22 \\
{[-0.6]}\end{array}$ \\
\hline Constraint on executive in 1900 & & & & & & & & & & $\begin{array}{l}0.11 \\
{[0.7]}\end{array}$ & & & & & & & & $\begin{array}{l}0.15 \\
{[0.3]}\end{array}$ \\
\hline Terms of trade volatility & & & & & & & & & & & & $\begin{array}{l}0.05 \\
{[0.6]}\end{array}$ & & & & & & $\begin{array}{l}0.14^{\times} \\
{[1.6]}\end{array}$ \\
\hline Debt-GDP ratio in 1900 & & & & & & & & & & & & & & $\begin{array}{l}-0.68 \\
{[-0.9]}\end{array}$ & & & & $\begin{array}{l}-0.57 \\
{[-0.7]}\end{array}$ \\
\hline Currency crashes in mid 20th century & & & & & & & & & & & & & & & & $\begin{array}{l}4.08^{*} \\
{[1.8]}\end{array}$ & & $\begin{array}{l}3.45 \\
{[1.3]}\end{array}$ \\
\hline$R^{2}$ & & 0.04 & & 0.01 & & 0.11 & & 0.01 & & 0.01 & & 0.01 & & 0.02 & & 0.06 & & 0.25 \\
\hline Observations & & 52 & & 52 & & 52 & & 52 & & 52 & & 52 & & 52 & & 52 & & 52 \\
\hline
\end{tabular}

Notes: See Appendix 1 for definition and source of variables. t-statistics are in square brackets. Constant term is not reported.

$\times,{ }^{*},{ }^{* *}$ and ${ }^{* * *}$ indicate statistically significant at the $15 \%, 10 \%, 5 \%$ and $1 \%$ levels, respectively. 
Table 7

Instrumental variable cross-country regressions. Dependent variable is the correlation between the cyclical components of real government expenditure and GDP.

\begin{tabular}{|c|c|c|c|c|c|c|c|c|}
\hline & \multicolumn{7}{|c|}{ Instrumenting only for Av. IQ } & \multirow{2}{*}{$\frac{\text { Instrumenting for all right hand-side variables }}{(8)}$} \\
\hline & (1) & $(2)$ & (3) & (4) & (5) & (6) & (7) & \\
\hline Av. IQ & $\begin{array}{l}-1.39^{* * *} \\
{[-6.3]}\end{array}$ & $\begin{array}{l}-1.31^{* * *} \\
{[-5.4]}\end{array}$ & $\begin{array}{l}-1.43^{* * *} \\
{[-4.8]}\end{array}$ & $\begin{array}{l}-1.27^{* * *} \\
{[-5.0]}\end{array}$ & $\begin{array}{l}-1.32^{* * *} \\
{[-5.2]}\end{array}$ & $\begin{array}{l}-1.44^{* * *} \\
{[-5.5]}\end{array}$ & $\begin{array}{l}-1.51^{* * *} \\
{[-5.7]}\end{array}$ & $\begin{array}{c}-1.42^{* * *} \\
{[-2.6]}\end{array}$ \\
\hline Financial integration & & $\begin{array}{l}-0.02 \\
{[-0.7]}\end{array}$ & $\begin{array}{l}-0.03 \\
{[-1.2]}\end{array}$ & $\begin{array}{l}-0.03 \\
{[-1.3]}\end{array}$ & $\begin{array}{l}-0.04^{\times} \\
{[-1.6]}\end{array}$ & $\begin{array}{l}-0.03 \\
{[-1.4]}\end{array}$ & $\begin{array}{l}-0.04^{\times} \\
{[-1.6]}\end{array}$ & $\begin{array}{l}0.01 \\
{[0.1]}\end{array}$ \\
\hline Financial depth & & & $\begin{array}{l}0.31^{\times} \\
{[1.5]}\end{array}$ & $\begin{array}{l}0.48^{* * *} \\
{[2.6]}\end{array}$ & $\begin{array}{l}0.45^{* *} \\
{[2.6]}\end{array}$ & $\begin{array}{l}0.49^{* * *} \\
{[2.8]}\end{array}$ & $\begin{array}{l}0.55^{* * *} \\
{[3.1]}\end{array}$ & $\begin{array}{l}0.39 \\
{[0.6]}\end{array}$ \\
\hline Output volatility & & & & $\begin{array}{l}0.06^{* * *} \\
{[3.9]}\end{array}$ & $\begin{array}{l}0.06^{* * *} \\
{[3.9]}\end{array}$ & $\begin{array}{l}0.06^{* * *} \\
{[3.9]}\end{array}$ & $\begin{array}{l}0.07^{* * * *} \\
{[4.1]}\end{array}$ & $\begin{array}{l}-0.02 \\
{[-0.2]}\end{array}$ \\
\hline Checks and balances & & & & & $\begin{array}{l}0.02 \\
{[0.9]}\end{array}$ & $\begin{array}{l}0.02 \\
{[1.2]}\end{array}$ & $\begin{array}{l}0.03^{\times} \\
{[1.6]}\end{array}$ & $\begin{array}{l}-0.16 \\
{[-1.3]}\end{array}$ \\
\hline Debt-GDP ratio & & & & & & $\begin{array}{l}-0.04 \\
{[-0.9]}\end{array}$ & $\begin{array}{l}-0.07 \\
{[-1.3]}\end{array}$ & $\begin{array}{l}-0.17 \\
{[-0.5]}\end{array}$ \\
\hline Foreign reserves & & & & & & & $\begin{array}{l}-0.02 \\
{[-1.1]}\end{array}$ & $\begin{array}{c}-0.03 \\
{[-0.5]}\end{array}$ \\
\hline Overidentification test ( $p$-value) & 0.65 & 0.66 & 0.66 & 0.64 & 0.57 & 0.37 & 0.45 & 0.49 \\
\hline Weak identification tests ( $p$-value & & & & & & & & \\
\hline $\begin{array}{l}\text { For Av. IQ } \\
\text { For Financial integration } \\
\text { For Financial depth } \\
\text { For Output volatility } \\
\text { For Checks and balances } \\
\text { For Debt-GDP ratio } \\
\text { For Foreign reserves }\end{array}$ & $1.1 \times 10^{-11}$ & $7.6 \times 10^{-11}$ & $4.5 \times 10^{-9}$ & $4.2 \times 10^{-9}$ & $1.6 \times 10^{-8}$ & $7.2 \times 10^{-8}$ & $2 \times 10^{-6}$ & $\begin{array}{l}1.1 \times 10^{-11} \\
1.4 \times 10^{-3} \\
1.6 \times 10^{-9} \\
6.9 \times 10^{-5} \\
4.5 \times 10^{-7} \\
2.4 \times 10^{-2} \\
1.3 \times 10^{-3}\end{array}$ \\
\hline Observations & 52 & 52 & 52 & 52 & 52 & 52 & 52 & 52 \\
\hline
\end{tabular}

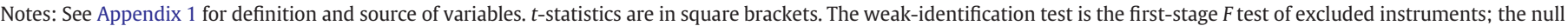

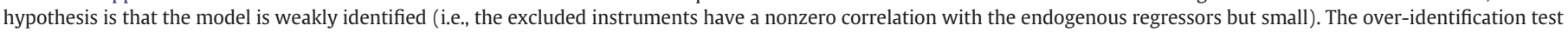
is the Hansen's J statistic; the null hypothesis is that the instruments are exogenous (i.e., uncorrelated with the error term). Constant term is not reported.

$\times, *, * *$ and ${ }^{* * *}$ indicate statistically significant at the $15 \%, 10 \%, 5 \%$ and $1 \%$ levels, respectively.

main data sources. Measured as total central government debt over GDP at the beginning of year. For Azerbaijan we used public and publicly guaranteed debt service. For Côte d'Ivoire, Haiti, Italy, Kuwait, Myanmar, Netherlands, New Zealand, Niger, Poland, Qatar, Romania, Singapore, Tanzania, and United Arab Emirates we used total general government debt. If a country was not independent in 1900 , we used the colonizer's respective ratio when measuring 1900 DebtGDP ratios.

\section{G. Foreign reserves}

World Development Indicators (WDI-World Bank) and International Financial Statistics (IFS-IMF) were the main data sources. Total reserves comprise holdings of monetary gold, special drawing rights, reserves of IMF members held by the IMF, and holdings of foreign exchange under the control of monetary authorities. The gold component of these reserves is valued at year-end (December 31) London prices. This item shows reserves expressed in terms of the number of months of imports of goods and services they could pay for [Reserves/(Imports/12)] at the end of previous year.

\section{H. Currency crashes in mid 20th century}

Reinhart and Rogoff (2011) and authors' calculations based on exchange rate data from Global Financial Data were the main data sources. An episode of currency crash is counted for the entire period in which annual depreciations exceed the threshold of $15 \%$ per annum. We calculate the average frequency of currency crashes for the period 19401960.

\section{I. Terms of trade of goods and services}

World Economic Outlook (WEO-IMF) was the main data source. Series TT (terms of trade, goods \& services) for WEO. Data period covers 1962-2009.

\section{J. Institutional quality}

International Country Risk Guide (ICRG) was the source of data. Institutional quality is a normalized index that ranges between 0 (lowest institutional quality) and 1 (highest institutional quality). The index was calculated by the authors as the average of four components: investment profile, corruption, law and order, and bureaucratic quality. Data period covers 1984-2008.

\section{K. Checks and balances}

Beck, Clarke, Groff, Keefer, and Walsh (2001) was the source of data. An 18-category scale, from 1 to 18 , with a higher score indicating more political checks and balances. Data period covers 1975-2009.

\section{L. European settler mortality}

Acemoglu et al. (2001) was the source of data. Mortality rates of soldiers, bishops, and sailors stationed in the colonies between the seventeenth and nineteenth centuries.

\section{M. Latitude}

Acemoglu et al. (2001) was the source of data. Absolute value of the latitude of the country (i.e., a measure of distance from the equator), scaled to take values between 0 and 1 , where 0 is the equator.

\section{N. Colonial dummies}

Acemoglu et al. (2001) was the source of data. Dummy indicating whether country was a British, French, German, Spanish, Italian, Belgian, Dutch, or Portuguese colony. 


\section{O. French legal origin dummy}

Acemoglu et al. (2001) was the source of data. Legal origin of the company law or commercial code of each country.

\section{P. Constraint on executive in 1900}

Acemoglu et al. (2001) was the source of data. Seven-category scale, from 1 to 7 , with a higher score indicating more constraints. Score of 1 indicates unlimited authority; score of 3 indicates slight to moderate limitations; score of 5 indicates substantial limitations; score of 7 indicates executive parity or subordination. Equal to 1 if country was not independent at that date.

\section{Q. Democracy in 1900}

An 11-category scale, from 0 to 10 , with a higher score indicating more democracy. Points from three dimensions: Competitiveness of Political Participation (from 1 to 3); Competitiveness of Executive Recruitment (from 1 to 2, with a bonus of 1 point if there is an election); and Constraints on Chief Executive (from 1 to 4 ). Equal to 1 if country not independent at that date.

\section{Appendix 2. Data on cyclicality of fiscal policy and institutions}

\begin{tabular}{|c|c|c|c|c|c|}
\hline \multirow[t]{2}{*}{ Country } & \multirow[t]{2}{*}{$\begin{array}{l}\text { Graduating } \\
\text { class }\end{array}$} & \multicolumn{3}{|c|}{$\begin{array}{l}\text { Country correlations between } \\
\text { the cyclical components of real } \\
\text { government expenditure and } \\
\text { real GDP }\end{array}$} & \multirow[t]{2}{*}{$\begin{array}{l}\text { Average } \\
\text { institutional } \\
\text { quality 1984-2008 }\end{array}$} \\
\hline & & $\begin{array}{l}\text { Average } \\
1960- \\
2009\end{array}$ & $\begin{array}{l}\text { Average } \\
1960- \\
1999\end{array}$ & $\begin{array}{l}\text { Average } \\
2000- \\
2009\end{array}$ & \\
\hline Algeria & RG & 0.35 & 0.48 & -0.56 & 0.46 \\
\hline Angola & SS & 0.33 & 0.16 & 0.67 & 0.41 \\
\hline Argentina & SS & 0.24 & 0.31 & 0.01 & 0.54 \\
\hline Australia* & EG & -0.42 & -0.41 & -0.79 & 0.87 \\
\hline Austria* & EG & -0.36 & -0.41 & -0.21 & 0.89 \\
\hline Azerbaijan & SS & 0.90 & 0.98 & 0.65 & 0.48 \\
\hline Bahrain & RG & 0.26 & 0.63 & -0.11 & 0.64 \\
\hline Bangladesh & SS & 0.59 & 0.60 & 0.59 & 0.31 \\
\hline Belgium* & EG & -0.09 & -0.09 & -0.16 & 0.85 \\
\hline Bolivia & RG & 0.20 & 0.24 & -0.87 & 0.38 \\
\hline Botswana & RG & 0.80 & 0.92 & -0.32 & 0.66 \\
\hline Brazil & RG & 0.15 & 0.16 & -0.18 & 0.54 \\
\hline Cameroon & SS & 0.77 & 0.80 & 0.02 & 0.47 \\
\hline Canada* & EG & -0.19 & -0.09 & -0.81 & 0.92 \\
\hline Chile & RG & 0.20 & 0.27 & -0.64 & 0.66 \\
\hline China & SS & 0.26 & 0.18 & 0.73 & 0.56 \\
\hline Colombia & SS & 0.04 & 0.00 & 0.17 & 0.46 \\
\hline $\begin{array}{l}\text { Congo, } \\
\text { Dem. } \\
\text { Rep. of }\end{array}$ & BS & -0.10 & -0.19 & 0.85 & 0.18 \\
\hline $\begin{array}{l}\text { Congo, Rep. } \\
\text { of }\end{array}$ & SS & 0.33 & 0.34 & 0.31 & 0.39 \\
\hline Costa Rica & RG & 0.26 & 0.35 & -0.69 & 0.61 \\
\hline Côte d'Ivoire & RG & 0.57 & 0.61 & -0.16 & 0.48 \\
\hline Denmark* & EG & -0.06 & -0.04 & -0.31 & 0.92 \\
\hline $\begin{array}{l}\text { Dominican } \\
\text { Rep. }\end{array}$ & SS & 0.57 & 0.57 & 0.63 & 0.49 \\
\hline Ecuador & SS & 0.24 & 0.26 & 0.12 & 0.50 \\
\hline Egypt & SS & 0.22 & 0.24 & 0.02 & 0.48 \\
\hline El Salvador & RG & 0.07 & 0.04 & -0.04 & 0.39 \\
\hline Finland* & EG & -0.56 & -0.56 & -0.52 & 0.93 \\
\hline France* & BS & -0.40 & -0.49 & 0.02 & 0.81 \\
\hline Gabon & SS & 0.71 & 0.72 & 0.34 & 0.45 \\
\hline Gambia & SS & 0.16 & 0.16 & 0.19 & 0.54 \\
\hline Germany* & RG & 0.19 & 0.33 & -0.33 & 0.87 \\
\hline Ghana & SS & 0.43 & 0.41 & 0.68 & 0.47 \\
\hline Greece* & BS & -0.17 & -0.18 & 0.21 & 0.65 \\
\hline
\end{tabular}

Appendix 2 (continued)

\begin{tabular}{|c|c|c|c|c|c|}
\hline \multirow[t]{2}{*}{ Country } & \multirow[t]{2}{*}{$\begin{array}{l}\text { Graduating } \\
\text { class }\end{array}$} & \multicolumn{3}{|c|}{$\begin{array}{l}\text { Country correlations between } \\
\text { the cyclical components of real } \\
\text { government expenditure and } \\
\text { real GDP }\end{array}$} & \multirow[t]{2}{*}{$\begin{array}{l}\text { Average } \\
\text { institutional } \\
\text { quality 1984-2008 }\end{array}$} \\
\hline & & $\begin{array}{l}\text { Average } \\
1960- \\
2009\end{array}$ & $\begin{array}{l}\text { Average } \\
1960- \\
1999\end{array}$ & $\begin{array}{l}\text { Average } \\
2000- \\
2009\end{array}$ & \\
\hline Guatemala & SS & 0.49 & 0.51 & 0.29 & 0.38 \\
\hline Haiti & SS & 0.34 & 0.34 & 0.47 & 0.19 \\
\hline Honduras & SS & 0.22 & 0.24 & 0.19 & 0.38 \\
\hline Hong Kong & RG & 0.26 & 0.41 & -0.52 & 0.74 \\
\hline India & SS & 0.24 & 0.15 & 0.51 & 0.57 \\
\hline Indonesia & RG & 0.33 & 0.40 & -0.24 & 0.40 \\
\hline Iran & SS & 0.56 & 0.57 & 0.77 & 0.49 \\
\hline Ireland* & EG & -0.08 & -0.01 & -0.32 & 0.82 \\
\hline Italy* & EG & -0.09 & -0.08 & -0.14 & 0.70 \\
\hline Jamaica & BS & -0.32 & -0.38 & 0.51 & 0.49 \\
\hline Japan* & EG & -0.22 & -0.11 & -0.56 & 0.82 \\
\hline Jordan & SS & 0.33 & 0.31 & 0.71 & 0.56 \\
\hline Kenya & SS & 0.51 & 0.48 & 0.74 & 0.52 \\
\hline Korea & EG & -0.06 & -0.01 & -0.52 & 0.65 \\
\hline Kuwait & BS & 0.07 & -0.14 & 0.29 & 0.57 \\
\hline Libya & RG & 0.02 & 0.45 & -0.26 & 0.48 \\
\hline Madagascar & SS & 0.47 & 0.53 & 0.29 & 0.50 \\
\hline Malaysia & RG & 0.39 & 0.48 & -0.74 & 0.63 \\
\hline Mali & SS & 0.58 & 0.62 & 0.36 & 0.31 \\
\hline Mexico & SS & 0.21 & 0.14 & 0.84 & 0.54 \\
\hline Morocco & RG & 0.43 & 0.46 & -0.10 & 0.58 \\
\hline Mozambique & SS & 0.25 & 0.26 & 0.25 & 0.45 \\
\hline Myanmar & SS & 0.66 & 0.65 & 0.73 & 0.29 \\
\hline Netherlands* & EG & -0.05 & -0.03 & -0.21 & 0.93 \\
\hline $\begin{array}{l}\text { New } \\
\text { Zealand* }\end{array}$ & SS & 0.05 & 0.01 & 0.55 & 0.91 \\
\hline Nicaragua & SS & 0.50 & 0.50 & 0.58 & 0.47 \\
\hline Niger & SS & 0.64 & 0.65 & 0.36 & 0.41 \\
\hline Nigeria & RG & 0.41 & 0.59 & -0.75 & 0.34 \\
\hline Norway* & RG & -0.01 & 0.18 & -0.88 & 0.89 \\
\hline Oman & RG & 0.71 & 0.76 & -0.06 & 0.61 \\
\hline Pakistan & SS & 0.37 & 0.37 & 0.42 & 0.42 \\
\hline Panama & SS & 0.16 & 0.10 & 0.85 & 0.41 \\
\hline Paraguay & RG & 0.53 & 0.63 & -0.14 & 0.38 \\
\hline Peru & SS & 0.67 & 0.65 & 0.87 & 0.43 \\
\hline Philippines & RG & 0.54 & 0.56 & -0.19 & 0.44 \\
\hline Portugal* & SS & 0.45 & 0.48 & 0.12 & 0.74 \\
\hline Qatar & SS & 0.69 & 0.58 & 0.68 & 0.54 \\
\hline Saudi Arabia & RG & 0.61 & 0.68 & -0.62 & 0.60 \\
\hline Senegal & SS & 0.47 & 0.46 & 0.75 & 0.46 \\
\hline Sierra Leone & SS & 0.67 & 0.75 & 0.43 & 0.33 \\
\hline South Africa & SS & 0.09 & 0.06 & 0.28 & 0.62 \\
\hline Spain* & EG & -0.26 & -0.13 & -0.62 & 0.76 \\
\hline Sri Lanka & SS & 0.11 & 0.01 & 0.67 & 0.48 \\
\hline Sudan & BS & -0.15 & -0.17 & 0.18 & 0.29 \\
\hline Sweden* & BS & 0.08 & -0.28 & 0.27 & 0.91 \\
\hline Switzerland* & BS & -0.52 & -0.65 & 0.20 & 0.90 \\
\hline $\begin{array}{l}\text { Syrian Arab } \\
\text { Rep. }\end{array}$ & RG & 0.76 & 0.79 & -0.34 & 0.45 \\
\hline Tanzania & SS & 0.24 & 0.14 & 0.87 & 0.47 \\
\hline Thailand & SS & 0.23 & 0.22 & 0.35 & 0.58 \\
\hline Togo & SS & 0.50 & 0.51 & 0.83 & 0.35 \\
\hline $\begin{array}{l}\text { Trinidad and } \\
\text { Tobago }\end{array}$ & SS & 0.76 & 0.77 & 0.73 & 0.58 \\
\hline Tunisia & SS & 0.48 & 0.48 & 0.73 & 0.55 \\
\hline Turkey & RG & 0.15 & 0.47 & -0.70 & 0.54 \\
\hline Uganda & RG & 0.04 & 0.05 & -0.02 & 0.42 \\
\hline $\begin{array}{c}\text { United Arab } \\
\text { Emirates }\end{array}$ & RG & -0.04 & 0.05 & -0.12 & 0.57 \\
\hline $\begin{array}{l}\text { United } \\
\text { Kingdom* }\end{array}$ & EG & -0.52 & -0.53 & -0.43 & 0.87 \\
\hline $\begin{array}{l}\text { United } \\
\text { States* }\end{array}$ & EG & -0.35 & -0.16 & -0.94 & 0.87 \\
\hline Uruguay & SS & 0.31 & 0.27 & 0.81 & 0.50 \\
\hline Venezuela & SS & 0.45 & 0.40 & 0.68 & 0.44 \\
\hline Yemen & EG & -0.05 & -0.04 & -0.10 & 0.44 \\
\hline Zambia & RG & 0.16 & 0.18 & -0.37 & 0.43 \\
\hline
\end{tabular}

Notes: The abbreviations EG, SS, RG, and BS stand for established graduate, still in school, recent graduate, and back to school graduating classes, respectively. ${ }^{*}$ identifies industrial countries. 


\section{References}

Acemoglu, Daron, Johnson, Simon, Robinson, James A., 2001. The colonial origins of comparative development: an empirical investigation. American Economic Review 91 (5), 1369-1401.

Aizenman, Joshua, Marion, Nancy, 2003. The high demand for international reserves in the Far East: what is going on? Journal of the Japanese and International Economies 17 (3), 370-400.

Alesina, Alberto, Perotti, Roberto, 1996. Fiscal discipline and the budget process. American Economic Review 86 (2), 401-407.

Alesina, Alberto, Campante, Filipe, Tabellini, Guido, 2008. Why is fiscal policy often procyclical? Journal of the European Economic Association 6 (5), 1006-1036.

Beck, Thorsten, Clarke, George, Groff, Alberto, Keefer, Philip, Walsh, Patrick, 2001. New tools in comparative political economy: the Database of Political Institutions. World Bank Economic Review 15 (1), 165-176.

Buchanan, James M., 1967. Public Finance in Democratic Process. University of North Carolina Press, Chapel Hill.

Caballero, Ricardo, Krishnamurthy, Arvind, 2004. Fiscal policy and financial depth NBER Working Paper No. 10532.

Calderón, César, Schmidt-Hebbel, Klaus, 2008. Business cycles and fiscal policies: the role of institutions and financial markets. Central Bank of Chile Working Paper No. 481.

Chinn, Menzie D., Ito, Hiro, 2006. What matters for financial development? Capital controls, institutions, and interactions. Journal of Development Economics 81, 163-192.

Christiano, Lawrence, Eichenbaum, Martin, Rebelo, Sergio, 2011. When is the government spending multiplier large? Journal of Political Economy 119 (1), 78-121.

Didier, Tatiana, Hevia, Constantino, Schmukler, Sergio, forthcoming. How resilient were emerging economies to the global crisis? Journal of International Money and Finance.

Easterly, William, Levine, Ross, 2003. Tropics, germs, and crops: how endowments influence economic development. Journal of Monetary Economics 50 (1), 3-39.

Frankel, Jeffrey, 2011. Over-optimism in forecasts by official budget agencies and its implications. Oxford Review of Economic Policy 27 (4). NBER Working Paper No.17239.

Frankel, Jeffrey, forthcoming. A solution to fiscal procyclicality: The structural budget institutions pioneered by Chile. Fiscal Policy and Macroeconomic Performance, edited by Luis Felipe Céspedes and Jordi Galí (Central Bank of Chile). NBER Working Paper No.16945.

Gavin, Michael, Perotti, Roberto, 1997. Fiscal policy in Latin America. NBER Macroeconomics Annual 12, 11-61.

Gavin, Michael, Hausmann, Ricardo, Perotti, Roberto, Talvi, Ernesto, 1996. Gestión de la política fiscal en América Latina y el Caribe: volatilidad, propensión a los ciclos y solvencia limitada. Inter-American Development Bank Working Paper No. 4033.

Glaeser, Edward L., La Porta, Rafael, Lopez-de-Silanes, Florencio, Shleifer, Andrei, 2004. Do institutions cause growth? Journal of Economic Growth 9 (3), 271-303.

Ilzetzki, Ethan, Vegh, Carlos A., 2008. Procyclical fiscal policy in developing countries: truth or fiction? NBER Working Paper No. 14191.

Kaminsky, Graciela, Reinhart, Carmen, Vegh, Carlos A., 2004. When it rains, it pours: procyclical capital flows and macroeconomic policies. NBER Macroeconomics Annual $19,11-82$
La Porta, Rafael, Lopez-de-Silanes, Florencio, Shleifer, Andrei, Vishny, Robert W., 1997. Legal determinants of external finance. Journal of Finance 52 (3), 1131-1150.

La Porta, Rafael, Lopez-de-Silanes, Florencio, Shleifer, Andrei, 2008. The economic consequences of legal origins. Journal of Economic Literature 46 (2), 285-332.

Lane, Philip R., 2003. The cyclical behaviour of fiscal policy: evidence from the OECD. Journal of Public Economics 87, 2661-2675.

Levine, Ross, Loayza, Norman, Beck, Thorsten, 2000. Financial intermediation and growth: causality and causes. Journal of Monetary Economics 46, 31-77.

Levine, Ross, Beck, Thorsten, Demirguc-Kunt, Asli, 2010. Financial institutions and markets across countries and over time: the updated financial development and structure database. World Bank Economic Review 10 (4), 77-92.

Loayza, Norman, Ranciere, Romain, 2006. Financial development, financial fragility, and growth. Journal of Money, Credit, and Banking 38, 1051-1076.

Mendoza, Enrique, Oviedo, Marcelo, 2006. Fiscal policy and macroeconomic uncertainty in developing countries: the tale of the tormented insurer. NBER Working Paper No. 12586. .

Nakata, Taisuke, 2011. Optimal fiscal and monetary policy with occasionally binding zero bound constraints, mimeo, New York University.

Persson, Torsten, Tabellini, Guido, 2004. Constitutional rules and fiscal policy outcomes. American Economic Review 94 (1), 25-45.

Poterba, James, von Hagen, Jürgen, 1999. Fiscal Institutions and Fiscal Performance. University of Chicago Press, Chicago.

Reinhart, Carmen M., Rogoff, Kenneth, 2011. From financial crash to debt crisis. American Economic Review 101 (5), 1676-1706.

Reinhart, Carmen M., Rogoff, Kenneth, Qiang, Rong, 2010. On graduation from default, inflation and banking crises: elusive or illusion? NBER Working Paper No. 16168

Riascos, Alvaro, Vegh, Carlos A., 2003. Procyclical government spending in developing countries: The role of capital market imperfections, (mimeo, UCLA and Banco Republica, Colombia).

Rodrik, Dani, Trebbi, Francesco, Subramanian, Arvind, 2004. Institutions rule: the primacy of institutions over integration and geography in economic development. Journal of Economic Growth 9 (2), 131-165.

Stiglitz, Joseph, 2006. Making Globalization Work. W.W. Norton.

Talvi, Ernesto, Vegh, Carlos A., 2005. Tax base variability and procyclicality of fiscal policy. Journal of Development Economics 78 (1), 156-190.

Tornell, Aaron, Lane, Philip R., 1999. The voracity effect. American Economic Review 89 (1), 22-46.

Vegh, Carlos A., Vuletin, Guillermo, 2012. How is tax policy conducted over the business cycle? NBER Working Paper No. 17753.

Vegh, Carlos A., Vuletin, Guillermo, forthcoming. Overcoming the fear of free falling: Monetary policy graduation in emerging markets, The Role of Central Banks in Financial Stability: How Has It Changed?, edited by Douglas Evanoff, Cornelia Holthausen, George Kaufman, and Manfred Kremer (Federal Reserve Bank of Chicago and European Central Bank).

Velasco, Andrés, 1997. A model of endogenous fiscal deficits and delayed fiscal reforms. NBER working paper $\mathrm{N}^{\mathrm{O}} 6336$.

von Hagen, Jürgen, Harden, Ian, 1995. Budget processes and commitment to fiscal discipline. European Economic Review 39, 771-779. 